\title{
The warm water inflow into the western tropical Atlantic boundary regime, spring 1994
}

\author{
Friedrich A. Schott, Lothar Stramma, and Jürgen Fischer \\ Institut für Meereskund: an der Universität Kiel. Kiel. Germany
}

\begin{abstract}
During March 1994 a survey of the western boundary of the tropical Atlantic, between $10^{\circ} \mathrm{N}$ and $10^{\circ} \mathrm{S}$, was carried out by conductivity-temperature-depth and current profiling using shipboard and lowered acoustic Doppler current profilers. In the nearsurface layer, above $\sigma_{(\rightarrow)}=24.5$, the inflow into the boundary regime came dominantly from low latitudes; out of the $14 \mathrm{~Sv}$ that crossed the equator in the upper part of the North Brazil Current (NBC), only $2 \mathrm{~Sv}$ originated from south of $5^{\circ} \mathrm{S}$, while $12 \mathrm{~Sv}$ came in from the east at $1^{\circ}-5^{\circ} \mathrm{S}$ with the South Equatorial Current (SEC). After crossing the cquator near $44^{\circ} \mathrm{W}$, only a minor fraction of the near-surface NBC retroflected eastward, while a net through flow of about $12 \mathrm{~Sv}$ above $\sigma_{\Theta}=24.5$ continued northwestward along the boundary. By contrast, in the isopycnal range $\sigma_{\Theta}=24.5-26.8$ encompassing the Equatorial Undercurrent (EUC), the source waters of the equatorial circulation were dominantly of higher-latitude South Atlantic origin. While only $3 \mathrm{~Sv}$ of eastern equatorial " ater entered the region through the SEC at $3^{\circ}-5^{\circ} \mathrm{S}$, there was an inflow of $10 \mathrm{~Sv}$ of South Atlantic water in the North Brazil Undercurrent (NBUC) along the South American coast that originated south of $10^{\circ} \mathrm{S}$. The transport of $14 \mathrm{~Sv}$ arriving at the equator along the boundary in the undercurrent layer was almost entirely retroflected into the EUC with only marginal northern water additions along its path to $35^{\circ} \mathrm{W}$. The offequatorial undercurrents in the upper thermocline, the South and North Equatorial Lndercurrents carried only small transports across $35^{\circ} \mathrm{W}$, of $5 \mathrm{~Sv}$ and $3 \mathrm{~Sv}$, respectively, dominantly supplied out of SEC recirculation rather than out of the boundary current. Still deeper, three zonal undercurrents were observed: the westward-flowing Equatorial Intermediate Current (EIC) in the depth range 200-900 m below the EUC, and two offcquatorial castivard undercurrents, the Northern and Southern Intermediate

Countercurrents (NICC, SICC) at 400-1000 $\mathrm{m}$ and $1^{\circ}-3^{\circ}$ latitude. In the lower part of the NBUC there was an Antarctic Intermediate Water (AAIW) inflow along the coast of $6 \mathrm{~Sv}$, and there was a clear connection at the AAIW level to the SICC by low salinities and high oxygens and a weaker suggestion also that some supply of the NICC might be through AAIW out of the decp NBUC.
\end{abstract}

\section{Introduction}

The near-surface circulation of the western tropical Atlantic, south of the equator, is characterized by broad westward inflow through the South Equatorial Current (SEC) that carrics water masses with subsurface salinity and oxygen values resembling those of the eastern South Atlantic [Reid, 1989: Tsuchiva, 1986]. Near the boundary. this flow splits up into a northerly component that supplies the cross-equatorial western boundary current. the North Brazil Current (NBC) and into a southerly recirculation as part of the anticyclonic subtropical South Atlantic gyrc. South of the equator, two eastw ard flowing zonal currents have been obsered. the South Equatorial Undercurrent (SEUC) in the latitude range $3^{\circ}-5 \circ \mathrm{S}$. for which Cochrane ct al. [1979] reported a transport of $15 \mathrm{~Sv}$ eastward in the longitude range $25^{\circ}-33^{\circ} \mathrm{W}$, and a South Equatorial Countercurrent (SECC) in the latitude range $7^{\circ}-9^{\circ} \mathrm{S}$. for which. however. only sparse evidence has been produced so far for the western tropical South Atlantic [e.g., Molinari. 1982: Stramma, 19911 .

Copsright 1995 by the American Gcophysical Union.

Paper number 95J(0)

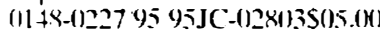

As regards the scasonal signal south of the equator, ship drift currents [Richardson and Walsh, 1986; Amault. 1987], evaluation of the historical expendable bathythermograph (XBT) data file [.1Folinari and Jolm. 1994]. and satellite altimctry [e.g.. Romaneessen. 1993] suggest that it is small compared with the region of the North Equatorial Countercurrent (NECC) regime. After an evaluation of the high-resolution World Occan Circulation Experiment Community Modeling Effort (WOCE CME) model of the North Atlantic revealing that the northward flowing boundary current off North Brazil, between $5^{\circ} \mathrm{S}$ and $10^{\circ} \mathrm{S}$. was in fact an equatonsard undercurrent [Schott and Böming, 1991]. recent observational programs confirmed that undercurrent structure from direct velocity profiles [Stramma et al., 1995]; it also can be seen in geostrophic results of older Nansen bottle sections [Silseira et al., 1994]. The North Brazil Undercurrent (NBUC) was found to be quasi-continuous along the coast. between $10^{\circ} \mathrm{S}$ and $5^{\circ} \mathrm{S}$, with very little inflow out of the SEC in that latitude range. However. after passing Cape San Roque at $5^{\circ}$ S. the SEC overrides the NBUC, causing its structure to change from an undercurrent to a surface-intensified current, the North Brazil Current.

The NBC, after crossing the equator, partially continues northwestward, partially retroflects into the Equatorial Under- 
current (EUC) and the NECC; part of it may also end up in the North Equatorial Undercurrent (NEUC). How this partition works and what kind of seasonality it has are still to be determined. The NECC is heavily supplied via cross-equatorial inflow during July to December or January, expressed by a strong surface current retroflection near $3^{\circ}-5^{\circ} \mathrm{N}$ [Johns et al., 1990; Didden and Schott, 1992], while in spring to early summer the NECC is weak or even flowing westward [Richardson and Reverdin, 1987]. The NECC can also be supplied from the north, as was determined by Wilson et al. [1994] for August 1989, when significant transports out of the NEC turned southward near the western boundary and joined the NECC. Part of this NEC recirculation even transited through the eastern Caribbean. This southwestward NEC recirculation was also reproduced in the CME model [Schott and Böning, 1991].

Water mass transfer out of the retroflection zone partially occurs through eddy shedding, and detached anticyclonic rings have been observed to propagate along the South American coast toward the entrances of the Caribbean by surface color measurements [Müller-Karger et al., 1988; Johns et al., 1990], by trapped drifters [Richardson et al., 1994], and in Geosat altimetry [Didden and Schott, 1993]. The weakness and even reversal of the NECC in spring, combined with only weak seasonality of the SEC inflow, was presumed to result in increased northwestward transport out of the NBC toward the Caribbean in spring [Richardson and Philander, 1987], but so far, evidence for this transport cycle could not be produced [e.g., Didden and Schott, 1992].

At intermediate levels, Antarctic Intermediate Water (AAIW), identifiable by its oxygen maximum and salinity minimum, spreads northward along the western boundary [Tsuchiya, 1989], involving complex pathways in the western tropical Atlantic, as evidenced by the 800 -m-level float tracks of Richardson and Schmitz [1993]. Below, there arc the northern extensions of upper Circumpolar Deep Water (uCDW), characterized by nutrient maxima [Reid, 1989]. The deep reaching NBUC is one of the current branches affecting water mass redistribution down to these levels.

In the Pacific, three zonal intermediate-depth currents have been documented in the equatorial regime [Firing, 1987; Gouriou and Toole, 1993]: the Equatorial Intermediate Current (EIC), flowing westward underneath the EUC, at 300- to 700-m depth, and two off-equatorial eastward intermediate currents, the Southern and Northern Intermediate Countercurrents (SICC, NICC), at $1.5^{\circ}-2^{\circ}$ latitude and 400 - to $1500-\mathrm{m}$ depth. In the Atlantic, evidence in the past has been produced for the existence of the EIC [Stalcup and Metcalf, 1966; Hisard and Rual, 1970]; as for the off-equatorial intermediate countcrcurrents, it is still an open question whether they also exist in the Atlantic and, if so, what role they play in the AAIW circulation.

Quantitatively, not very much is known about these different branches of the near-boundary circulation because geostrophy degenerates in the near-equatorial zone and direct current observations were not available until recently. The transport of the NBC at the equator was determined by Schott et al. [1993] with a moored acoustic Doppler current profiler (ADCP) and current meter array near $44^{\circ} \mathrm{W}$. It amounted to an annual mean of $24 \mathrm{~Sv}$ for the upper $300 \mathrm{~m}$ with an annual cycle of only $3 \mathrm{~Sv}$ amplitude. Ship sections of the region show that a large fraction of this transport retroflects into the EUC; hence only part of it is water mass gain for the northern hemisphere. Ship profiling measurements from Meteor cruise M22/2 from No- vember 1992 across the NBUC at $5^{\circ} \mathrm{S}$ and $10^{\circ} \mathrm{S}$ were evaluated by Stramma et al. [1995]. The transport of the upper $1000 \mathrm{~m}$ was $22 \mathrm{~Sv}$ with no net inflow joining the NBUC between $10^{\circ} \mathrm{S}$ and $5^{\circ} \mathrm{S}$, indicating a source supply even farther south along the coast. Silveira et al. [1994] computed an average geostrophic transport of the equatorward boundary current of $21 \mathrm{~Sv}$ for May-July 1986.

A survey of the NBUC-NBC system and the near-equatorial zonal currents during a different season, in March 1994, that is, when the NECC is at its minimum or flowing westward, was carried out on Meteor cruise M27/3 (Figure 1). Currents and transports were directly measured by ADCP profiling along several sections. This paper presents currents, transports, and water mass distributions from these measurements, and it at tempts to determine connections among the different current branches and an assessment of pathways of the major water masses involved for this particular season. Some comparisons will be made with recent findings in the western Pacific because significant similarities of current patterns among the two oceans are found.

\section{Observations}

The tropical survey began on February 26 at $12^{\circ} \mathrm{N}$, continued along the $44^{\circ} \mathrm{W}$ section (Figure 1), and terminated that section on March 5 at the equator. The $40^{\circ} \mathrm{W}$ section was done during March 7-11 and the $35^{\circ} \mathrm{W}$ section during March 13-17; finally; the measurements around the southern box, between $5^{\circ} \mathrm{S}$ and $10^{\circ} \mathrm{S}$, were carried out during March 18-25. The conductivitytemperature-depth (CTD) system used was Neil Brown Mark III with bottle calibrations. The pressure and temperature sensors were calibrated in the laboratory before the expedition. and these calibrations were verified by reversing thermometer temperature measurements and thermometric pressure measurements. The conductivity cell was calibrated from salinity bottle samples, as the cell showed some pressure dependence and a slight time dependence. The resulting salinity accuracy is \pm 0.003 . The oxygen sensor was calibrated from bottle oxygen samples analyzed by a modified Winkler titration. The accuracy of the calibrated sensor data is estimated at \pm 0.07 $\mathrm{mL} \mathrm{L}^{-1}$.

Current profiling was carried out by undenvay shipboard ADCP and by lowered ADCP (LADCP) on stations, mounted to the $\mathrm{CTD}$ /rosette (Figure 1). The depth range of the shipboard 153.6-kHz ADCP of the Meteor was much improved compared with prior cruises because a protective cover over the transducers had been removed in the shipyard just prior to the cruise. Hence in fair weather, ranges of 350-400 m were reached routinely where the uppermost reliable measurement was from $25-\mathrm{m}$ depth. The vertical resolution was $8 \mathrm{~m}$. Approximately 250 individual profiles were averaged into 5-min ensembles for storage.

In order to remove the contributions of the ships motion, the ADCP measurements have to be corrected for any transducer-gyrocompass misalignment before subtracting speed over ground (from Global Positioning System (GPS) positioning). A heading calibration similar to that of Pollard and Read [1990] was applied. For this procedure it is assumed that the vertically average current at a CTD station (at low ship speeds) is the same as that just before arriving at or after leaving the station. Any difference in the mean currents should then come from a deviation of the transducer axis relative to the gyrocompass. 


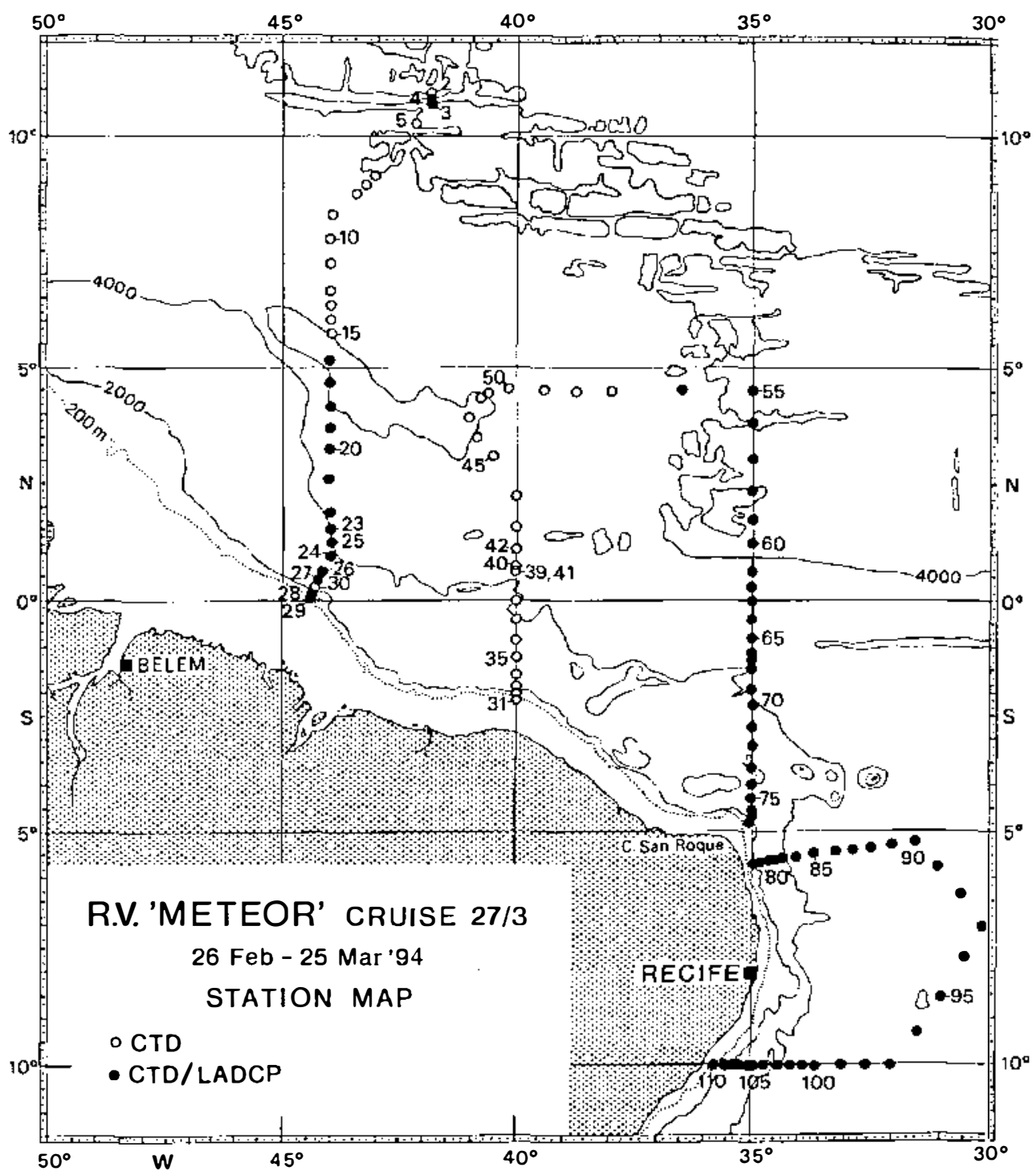

Figure 1. Conductivity-temperature-depth (CTD) stations with (solid circles) and without (open circles) lowered acoustic Doppler current profiler (LADCP) profiles of Meteor cruise M27, leg 3.

By rotating the currents so that the differences between on-station and off-station currents are minimized, a mean misalignment angle (or heading bias) is determined. Usually, all stations of a cruise are used to obtain a best estimate of the heading bias unless the transducer orientation changes during the cruise. During M27, however, a much larger error occurred due to a failure in the ship's gyrosystem. The automatic speed error compensation unit was not functioning, resulting in course and speed dependent heading deviations of up to $5^{\circ}$ between reversing (north to south) section orientations. Along the individual sections of the cruise the deviation was fairly constant and was not expected to have an effect on the quality of the raw data. Therefore we decided to calibrate each section separately for the combined effect of transducer misalignment and gyro error.

The accuracy of the heading calibration depends crucially on the number of stations of the sections; it was smallest $\left(\sim 0.2^{\circ}\right)$ along the major sections and about twice as large along the connecting lines, that is, along $4^{\circ} 30^{\prime} \mathrm{N}$ and $30^{\circ} \mathrm{W}$ (Figure 1). On the transit leg along the shelf between $44^{\circ} \mathrm{W}$ and $40^{\circ} \mathrm{W}$, no calibration could be performed, and the data were omitted. After the heading calibration, speed over ground from the ship's GPS system was subtracted to obtain absolute currents, which then were smoothed by a two-dimensional Gaussian filter (cutoff scales were $0.2^{\circ}$ horizontally and $20 \mathrm{~m}$ vertically) and regridded to $0.1^{\circ}(\sim 10 \mathrm{~km})$ resolution. The estimated error of the end product has two constituents, a bias arising from any residual heading misalignment of $\sim 2-4 \mathrm{~cm} \mathrm{~s}^{-1}$, and a stochastic error (order of $5 \mathrm{~cm} \mathrm{~s}^{-1}$ ) resulting from GPS inaccuracies and from noise in the ADCP data. While the latter will be reduced by integration along sections, the bias will introduce systematic errors in the transport calculations.

For the LADCP, two $153.6-\mathrm{kHz}$ systems were available, one narrowband (NB) and one broadband (BB). The BB system showed a temperature dependent failure that had already occurred on a previous cruise but had been presumably corrected by the manufacturer. Unfortunately, along the $40^{\circ} \mathrm{W}$ section, the NB also failed for some stations but it was back in operation for the rest of the cruise. The processing of the LADCP data and derivation of absolute profiles of north and east 

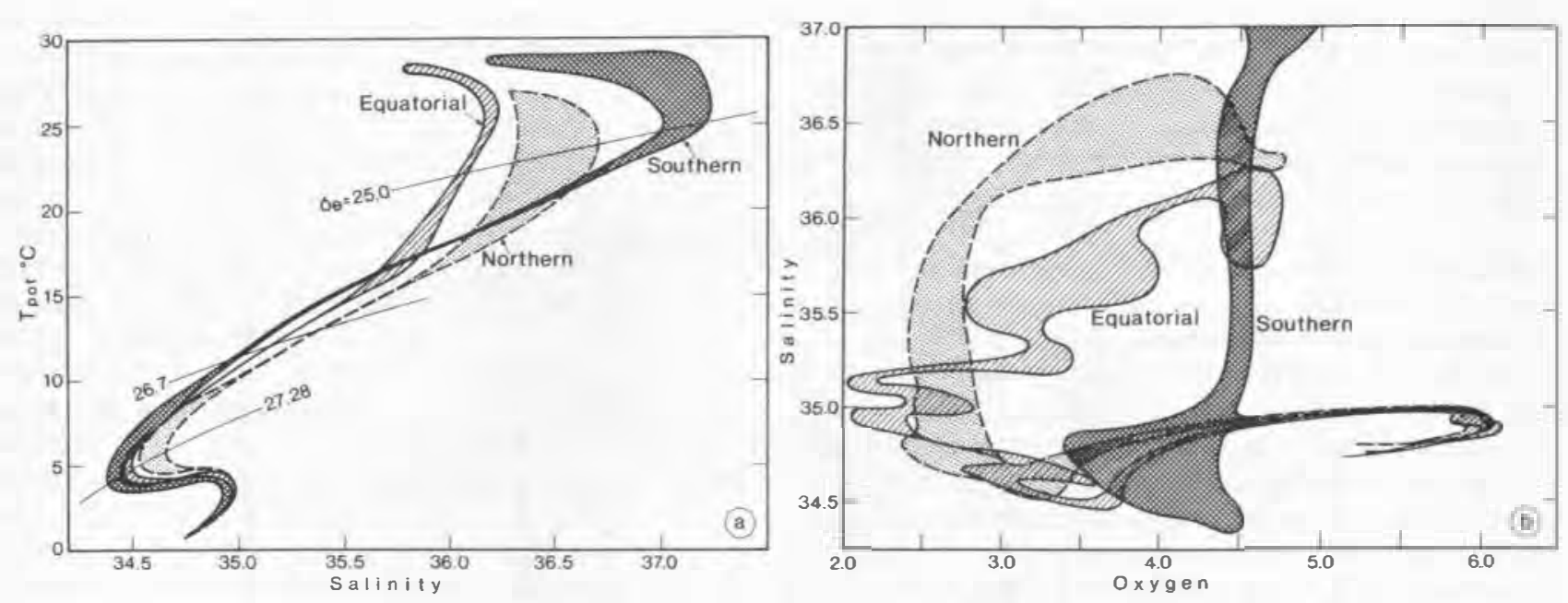

Figure 2. Northern versus southern and equatorial water mass contrast: (a) $(-)-S$ and (b) $\mathrm{O}_{2}-\mathrm{S}$ diagrams for stations $8-12$, along $44^{\circ} \mathrm{W}$, stations $79,80,104,109$, and 110 along $5^{\circ}$ and $10^{\circ} \mathrm{S}$ near the coast, and stations $66-68$ in equatorial waters (see Figure 1 for positions).

components were carried out as described by Fischer and Visbeck [1993].

LADCP errors of the order of $5 \mathrm{~cm} \mathrm{~s}^{-1}$ are a combination of noise in the ADCP measurements, of GPS position inaccuracies, and of internal wave noise [Send, 1994]. Because these errors are random, their effect on transport calculations will be reduced according to the number of stations used for the integration.

\section{Water Mass Distributions}

The differences between water masses of southern origin that are introduced into the region via the NBUC from the south and those from the northern hemisphere are very obvious in their salinities and oxygens. A potential temperaturesalinity $((-)-S)$ diagram (Figure 2a) shows the typical linear relation in the thermocline range representing the Central Water, which is of slightly higher salinity for the northern hemisphere [e.g., Emery and Meincke, 1986]. The salinity maximum water is formed as high-salinity surface water in the subtropics and progresses equatorward as a subsurface salinity maximum, while the water above is salinity-poor owing to the high precipitation in the tropics. In the study region the salinity maximum is located at the top of the thermocline, at densities slightly below $\sigma_{(\rightarrow)}=25.0$, and it reaches salinities above 37.0 at $5^{\circ}-10^{\circ} \mathrm{S}$ while staying below 36.7 north of the equator (Figure 2a). At the lower end of the warm water sphere, near $\sigma_{\leftrightarrow}=$ 27.3, the Antarctic Intermediate Water shows up as a salinity minimum (Figure 2a)

While salinity differences between both regions are small in the linear range of the $(-)-S$ diagram, the oxygen differences in the salinity range $35-36$ are striking (Figure $2 b$ ): at $5^{\circ}-10^{\circ} \mathrm{S}$ near the coast the oxygen values exceed $4 \mathrm{~mL} \mathrm{~L}^{-1}$, while they stay below $3 \mathrm{~mL} \mathrm{~L}^{-1}$ in the thermocline layers of the northwestern boundary regime. The equatorial water flowing in from the east with the SEC is also characterized by lower oxygen than southern water in the Central Water range. The maximum at $6 \mathrm{~mL} \mathrm{~L}^{-1}$ is associated with the North Atlantic Deep Water (NADW) (Figure 2b).

The water mass distributions will be described here by property distributions on three core isopycnal surfaces. They are marked in the $(-)-S$ diagram and are also inserted into a composite plot of zonal currents with salinity along $35^{\circ} \mathrm{W}$ (Figure 3a) and oxygen (Figure 3b). The surface $\sigma_{\Theta}=25.0$, at a mean depth of $100 \pm 19 \mathrm{~m}$, lies just underneath the surface mixed layer in the northern part of the survey area and shows the distributions for the near-surface circulation and salinity maximum water; it also passes through the velocity core of the EUC (Figure 3a). The surface $\sigma_{\Theta}=26.7$, at a mean depth of $216 \pm 51 \mathrm{~m}$, runs through the cores of both off-equatorial undercurrents and passes underneath the EUC (Figure 3). Finally, the $\sigma_{(-)}=27.28$ surface, at a mean depth of $747 \pm 42$ $\mathrm{m}$, runs through the low-salinity core of the AAIW (Figure 3). At that level the NBUC is still quite vigorous in the equatorward direction, and there are three zonal undercurrents: the Equatorial Intermediate Current (EIC) and two off-equatorial currents, the Northern and Southern Intermediate Countercurrents (NICC, SICC) at $2^{\circ}-3^{\circ} \mathrm{N}$ and $1.5^{\circ}-2.5^{\circ} \mathrm{S}$, respectively (Figure 3).

On each of the three selected surfaces. we present the distributions of salinity and oxygen as well as a classification by water mass groups. The latter are superimposed on current vector maps derived from the shipboard ADCP for the upper two isopycnals and from LADCP for the intermediate layer. For $\sigma_{(\rightarrow)}=25.0$, these distributions are shown in Figure 4. Beginning with the distributions south of the equator, the salinity maximum water spreads northward along the South American coast within the NBUC between $10^{\circ} \mathrm{S}$ and $5^{\circ} \mathrm{S}$, and it reaches $44^{\circ} \mathrm{W}$ near the southern boundary via the NBC with a core maximum still at 36.87 (Figure $4 \mathrm{a}$ ). The highest oxvgen values do not enter the region along the coast at $10^{\circ} \mathrm{S}$ but come from off shore and also extend along the coast to $44^{\circ} \mathrm{W}$. It is interesting to note that the highest oxygen values in the nearshelf core are located offshore of the salinity maximum, suggesting two veins of boundary supply. The secondary oxygen maximum of $>4.5 \mathrm{~mL} \mathrm{~L}^{-1}$ extends southeastward from $2^{\circ} \mathrm{N}$ at $44^{\circ} \mathrm{W}$ (Figure $4 \mathrm{~b}$ ). From the northwest, along $3^{\circ}-4^{\circ} \mathrm{N}$, a wedge of salinities $>36.5$ protrudes into the region across $44^{\circ} \mathrm{W}$ but this wedge is located north of the offshore oxygen maximum (Figure 4b).

In the near-surface circulation determined by shipboard 

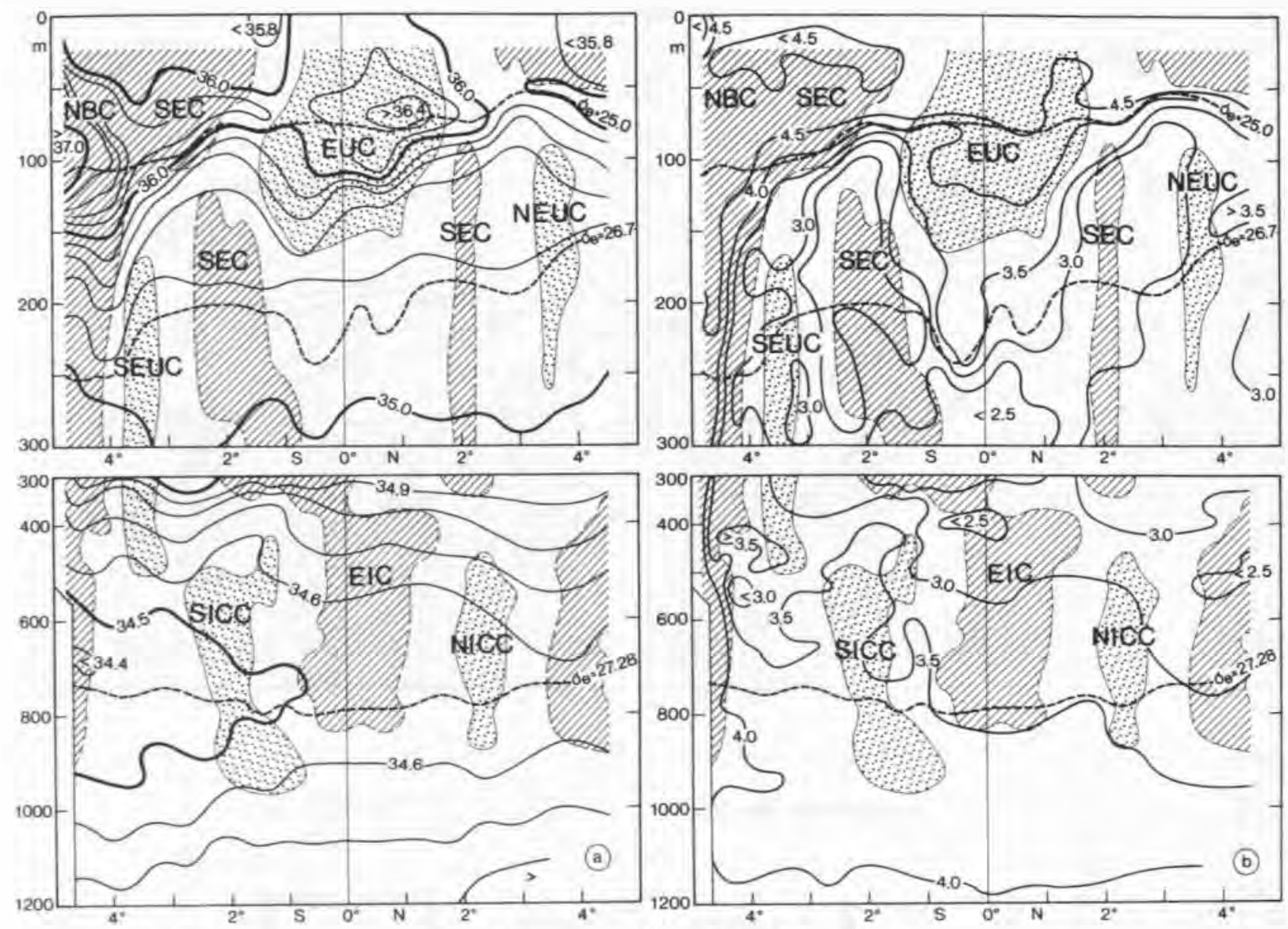

Figure 3. Distributions of water mass properties in the upper $1200 \mathrm{~m}$ along $35^{\circ} \mathrm{W}$ : (a) salinity and (b) oxygen in milliliters per liter. Current cores of different current branches are identified within the $20 \mathrm{~cm} \mathrm{~s}^{-1}$ contour in the upper $300 \mathrm{~m}$, except for SEUC and NEUC $\left(10 \mathrm{~cm} \mathrm{~s}{ }^{-1}\right.$ contour $)$ and within the $10 \mathrm{~cm}^{-1} \mathrm{~s}^{-1}$ contour in the range 300-1200 m. Also included (dashed lines) are the isopycnals of $\sigma_{\epsilon \rightarrow}=25.0, \sigma_{\Theta}=26.7$, and $\sigma_{\Theta}=$ 27.28. NBC, North Brazil Current; SEC, South Equatorial Current; EUC, Equatorial Undercurrent; SEUC and NEUC, South and North Equatorial Undercurrent; EIC, Equatorial Intermediate Current; SICC and NICC, Southern and Northern Intermediate Countercurrents.

ADCP (Figure 4c), the NBUC, which is weak at this nearsurface level, flows northward along the coast between $10^{\circ}$ and $5^{\circ} \mathrm{S}$, while the SEC enters the region across the $35^{\circ} \mathrm{W}$ section between $5^{\circ} \mathrm{S}$ and the equator. The joint current flows westward along the southern boundary, then crosses the $44^{\circ} \mathrm{W}$ section and suggests a retroflection at $2^{\circ}-4^{\circ} \mathrm{N}$ along that section. $\mathrm{Al}-$ though we cannot definitely conclude on the existence of that retroflection from the data at that level, we know from other work in progress that it exists west of $44^{\circ} \mathrm{W}$. That retroflection connects with eastward flows across $40^{\circ} \mathrm{W}$ just north of the equator and between $1.5^{\circ} \mathrm{S}$ and $2^{\circ} \mathrm{N}$ across the $35^{\circ} \mathrm{W}$ section. This is the upper part of the EUC (Figure 3). North of the EUC, the northern SEC branch supplies westward surface flow, including the regime normally occupied by eastward flowing NECC waters.

As regards the classification into water mass classes by their oxygens and salinities, one has to keep in mind that in the northern part of the region the $\sigma_{\omega}=25.0$ surface is only $10-20$ $\mathrm{m}$ below the surface mixed layer; hence properties at this level might not be conserved everywhere. Two dominant water mass characteristics can be distinguished at this level: those from the cquatorial belt and northwestern regime, and those from the southern hemisphere. If the water masses are marked as southern (Figures $4 \mathrm{a}$ and $4 \mathrm{~b})$ by their high oxygen $\left(>4.5 \mathrm{~mL} \mathrm{~L}^{-1}\right)$ and high salinities $(>36.8)$, and as equatorial and northern by relatively low oxygen $\left(<4.3 \mathrm{~mL} \mathrm{~L}^{-1}\right)$ and salinities $(<36.7)$, the class distribution as in Figure $4 \mathrm{c}$ results. From this classification the southern inflow at $\sigma_{\boldsymbol{\Theta}}=25.0$ originates not only from along the coast but also from the east between $5^{\circ} \mathrm{S}$ and $10^{\circ} \mathrm{S}$ (Figure 4c). Further, the boundary flow seems to continue to the west of $44^{\circ} \mathrm{W}$ because water masses of the retroflection differ from those along the boundary. Retroflection water at this level has mixed-water characteristics.

The surface $\sigma_{\boldsymbol{\Theta}}=26.7$ passes underneath the NBUC core at 250-m depth off Brazil, underneath the EUC at 200-m depth in the $35^{\circ} \mathrm{W}$ section, and through the core of the off-equatorial undercurrents (Figure 3 ). Its mean depth is $216 \pm 51 \mathrm{~m}$. At this level, southern water is marked by low salinity and high oxygen (Figure 2). This low-salinity (Figure 5a) and high-oxygen (Figure $5 b$ ) water spreads northward along the western boundary, and via the retroflection into eastward flow at $1.5^{\circ}-3.5^{\circ} \mathrm{N}$, which at this level and time of observation connects with the NEUC, while at the axis of the EUC at $40^{\circ}$ and $35^{\circ} \mathrm{W}$ we observed weak westward currents (Figure $5 \mathrm{c}$ ). The boundary 

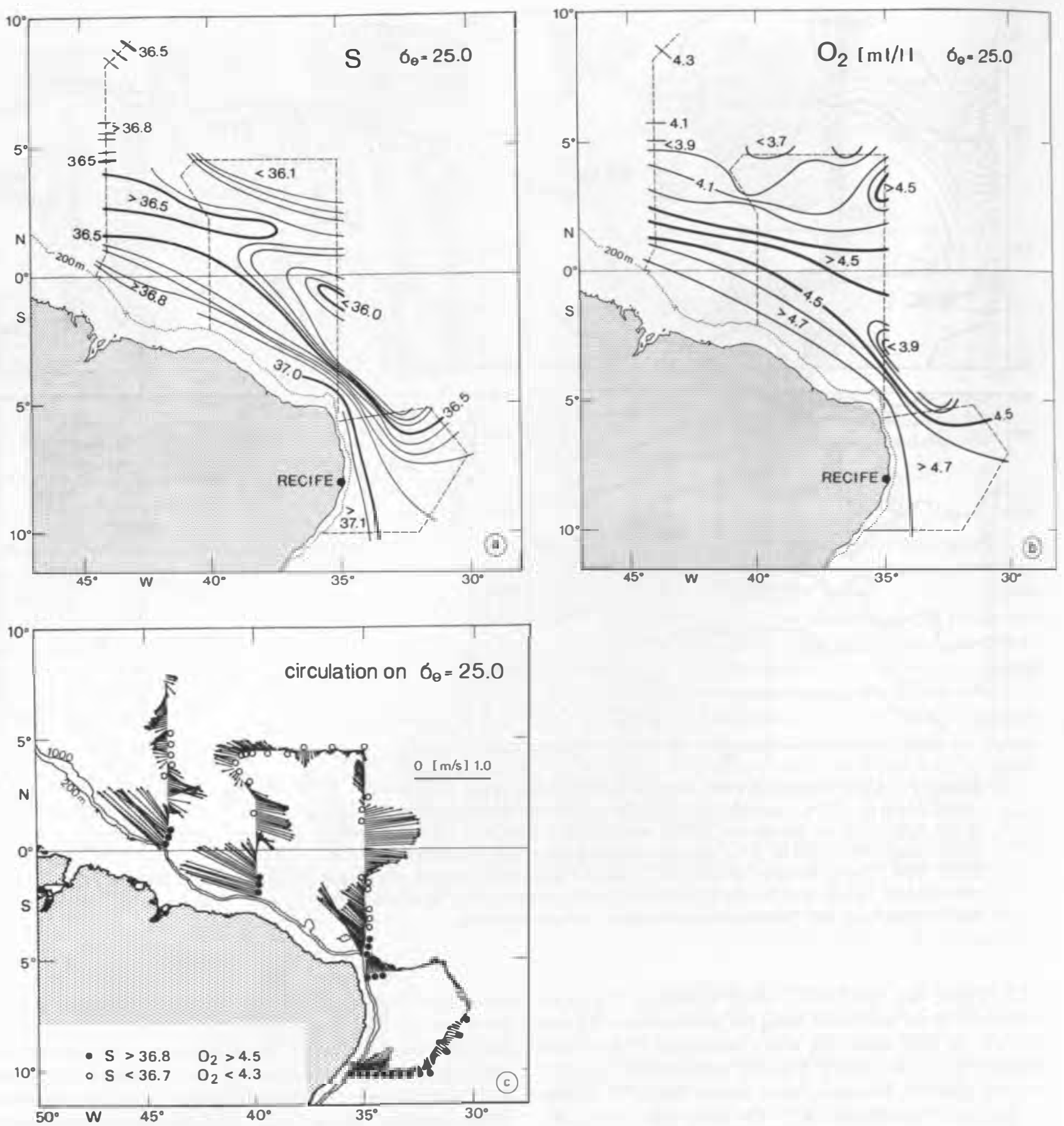

Figure 4. Distribution on isopycnal $\sigma_{(-)}=25.0$ of (a) salinity, (b) oxygen, and (c) current vectors from shipboard ADCP and water mass class (sec text for details). Open circles in Figure 4c denote equatorial and northern water mass properties; solid circles denote southern water mass properties.

currents at $5^{\circ}$ and $10^{\circ} \mathrm{S}$ (Figure 5c), compared with the $\sigma_{\leftrightarrow}=$ 25.0 level (Figure 4c) clearly show the undercurrent character of the NBUC. North of the NBC retroflection at $44^{\circ} \mathrm{W}$, at $3^{\circ}-4^{\circ} \mathrm{N}$, high-salinity water protrudes eastward, as was already seen at the level above. This indicates that at times the eastward zonal currents north of the equator can also be supplied by recirculation out of the NEC, as was found already by Wilson et al. [1994] for August 1989, a time of fully developed NECC. In our survey the frontal structure between northern and equatorial water in the latitude band normally occupied by the NECC, but in March covered by westward flow, could be the result of the returned NEC water in this westward current. It is interesting to note in Figures $4 \mathrm{c}$ and $5 \mathrm{c}$ that only weak zonal flow is found along the near-meridional $31^{\circ} \mathrm{W}$ section between $5^{\circ} \mathrm{S}$ and $10^{\circ} \mathrm{S}$ and that the southern hemispheric inflow into the western equatorial boundary regime occurs either along the coast from south of $10^{\circ} \mathrm{S}$ or zonally between $5 \mathrm{~S}$ and the equator.

Grouping water mass properties into southern (solid circles), northern (open circles), and equatorial (crosses) results in the distributions of Figure 5c. Inflow from the south is now only along the western boundary, not from the southeastern 

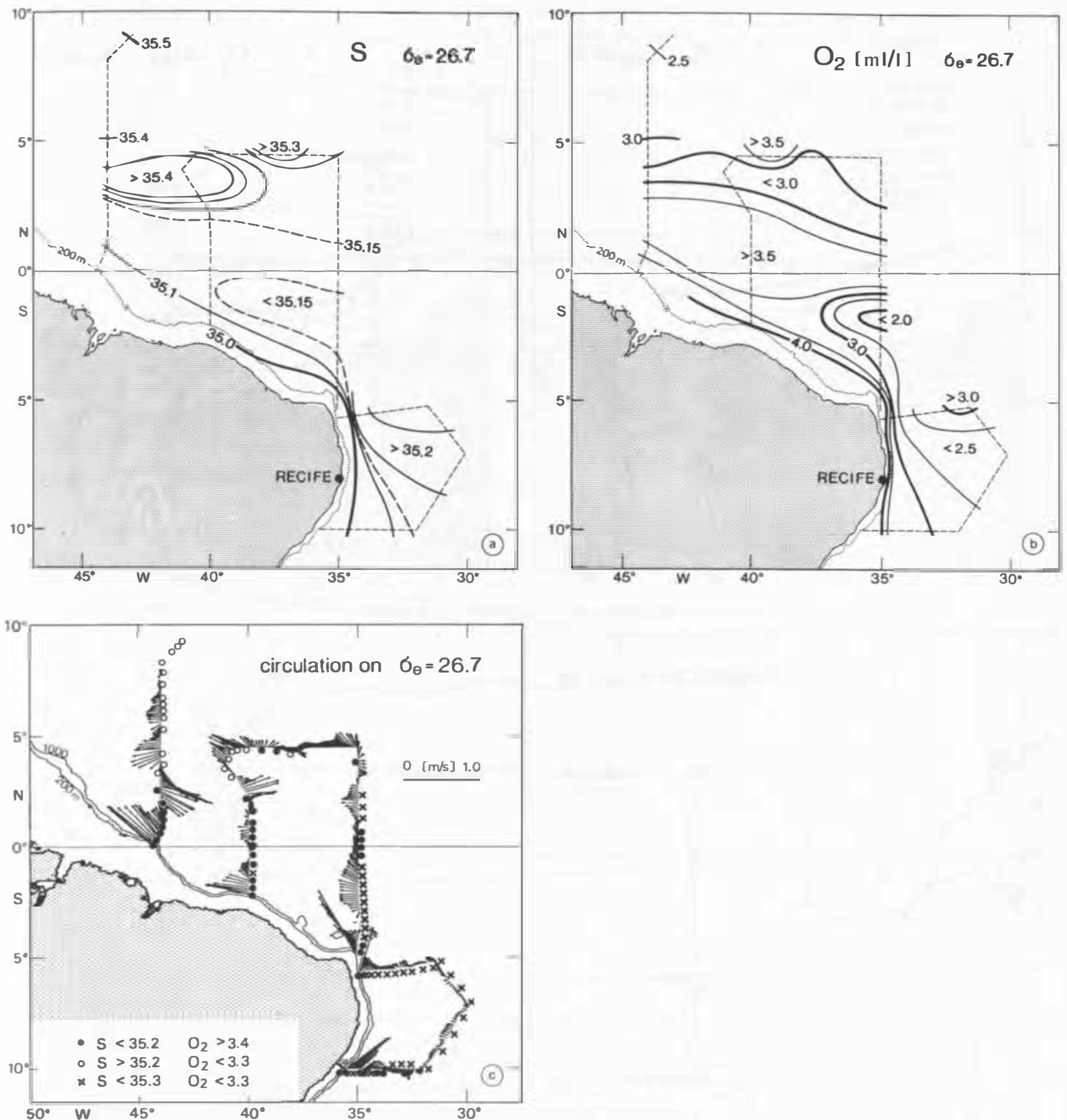

Fïgure 5. Same as Figure 4, but for $\sigma_{(-)}=26.7$. Solid circles in Figure 5c denote southern, crosses denote equatorial, and open circles denote northern water mass properties.

interior as near the surface. It connects with the equatorial interior via the retroflection at $44^{\mathrm{c}} \mathrm{W}$. From the water mass properties the lower part of the EUC is still supplied by the NBC (Figure 5c), although currents at the observation time were westward. Southern water mass properties also appear at isolated spots along $4^{\circ}-4.5^{\circ} \mathrm{N}$, suggesting partial feeding of the NEUC out of the crossequatorial flow.

Figure $5 \mathrm{c}$ shows the SEUC current core in the $35^{\circ} \mathrm{W}$ section at $3^{\circ}-4^{\circ} \mathrm{S}$, but an association of the SEUC at $35^{\circ} \mathrm{W}$ with boundary water mass properties is not possible; the SEUC core oxygen at $35^{\circ} \mathrm{W}$ is only at $3.0 \mathrm{~mL} \mathrm{~L}{ }^{-1}$, compared with $>4.0 \mathrm{~mL}$ $\mathrm{L}^{-1}$ in the NBUC (Figure 5b). This suggests that the SEUC is not supplied via a retroflection out of the NBUC, but rather is supplied by recirculation of interior water masses coming in with the lower part of the SEC.

At the $\sigma_{\Theta}=27.28$ level, salinities $<34.45$ (Figure 6a), accompanied by oxygen values $>4.2 \mathrm{~mL} \mathrm{~L}^{-1}$ (Figure $6 \mathrm{~b}$ ) mark the propagation of AAIW along the coast around Cape San Roque. Along $2^{\circ} \mathrm{S}$, an eastward extension of salinities $<34.45$ across the $35^{\circ} \mathrm{W}$ meridian is observed. This halinity minimum along $2^{\circ} \mathrm{S}$ is accompanied by an oxygen maximum (Figure $6 \mathrm{~b}$ ). This property tongue is associated with the southern hemispheric eastward current core (Figures 3 and $6 c$ ), suggesting eastward AAIW leakage out of the boundary current south of 

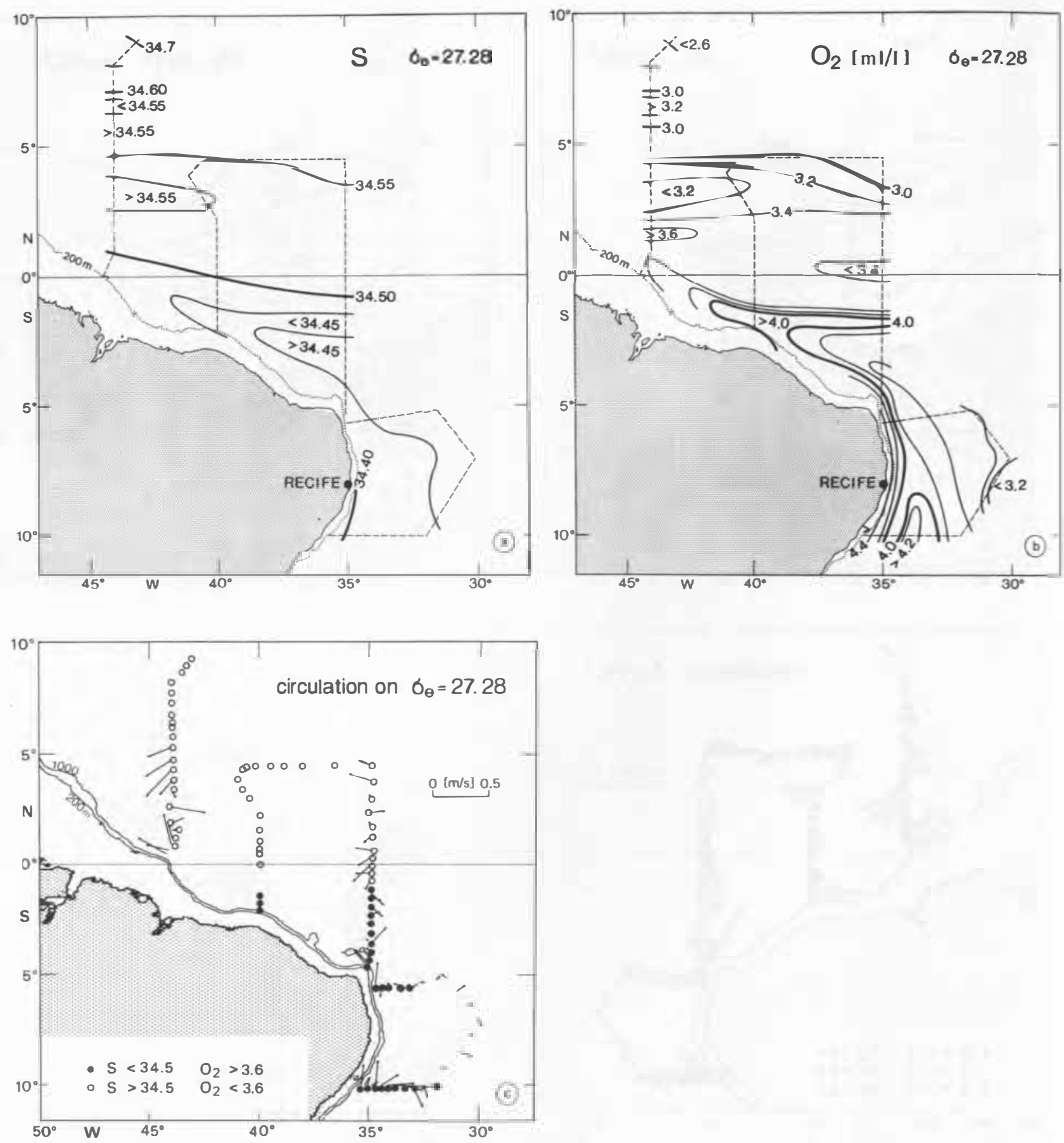

Figure 6. Same as Figure 4, but for $\sigma_{(-)}=27.28$ and individual station currents from LADCP.

the equator. The low-salinity, high-oxygen tongue reaches $44^{\circ} \mathrm{W}$ along the boundary with the bottom part of the NBC, indicating the AAIW transfer into the northern hemisphere. North of the equator, and away from the boundary, salinities increase gradually in the meridional direction. An oxygen maximum extends along $2^{\circ} \mathrm{N}$, which may suggest that the second off-equatorial eastward core, centered at $2^{\circ}-3^{\circ} \mathrm{N}$, could also be connected to the deep part of the NBC, although that is not supported by a clear salinity minimum signal. At $\sigma_{\leftrightarrow}=27.28$ the individual station LADCP currents are more noisy but show a clear continuance of the NBUC along the western boundary from $10^{\circ} \mathrm{S}$ to the equator near $44^{\circ} \mathrm{W}$. At $35^{\circ} \mathrm{W}$ the EIC is identifiable between $1.5^{\circ} \mathrm{S}$ and $1.5^{\circ} \mathrm{N}$; the Southern Intermediate Countercurrent (SICC) just south of the EIC is also clearly seen. North of $3.5^{\circ} \mathrm{N}$ there is westward flow in both the $35^{\circ} \mathrm{W}$ and $44^{\circ} \mathrm{W}$ sections. The eastward flow at $44^{\mathrm{c}} \mathrm{W}$. $2.5^{\circ} \mathrm{N}$, contains water in part from the NBC retroflection and in part from the north, suggesting admixtures of both water masses in the source region of the Northern Intermediate Countercurrent (NICC). 


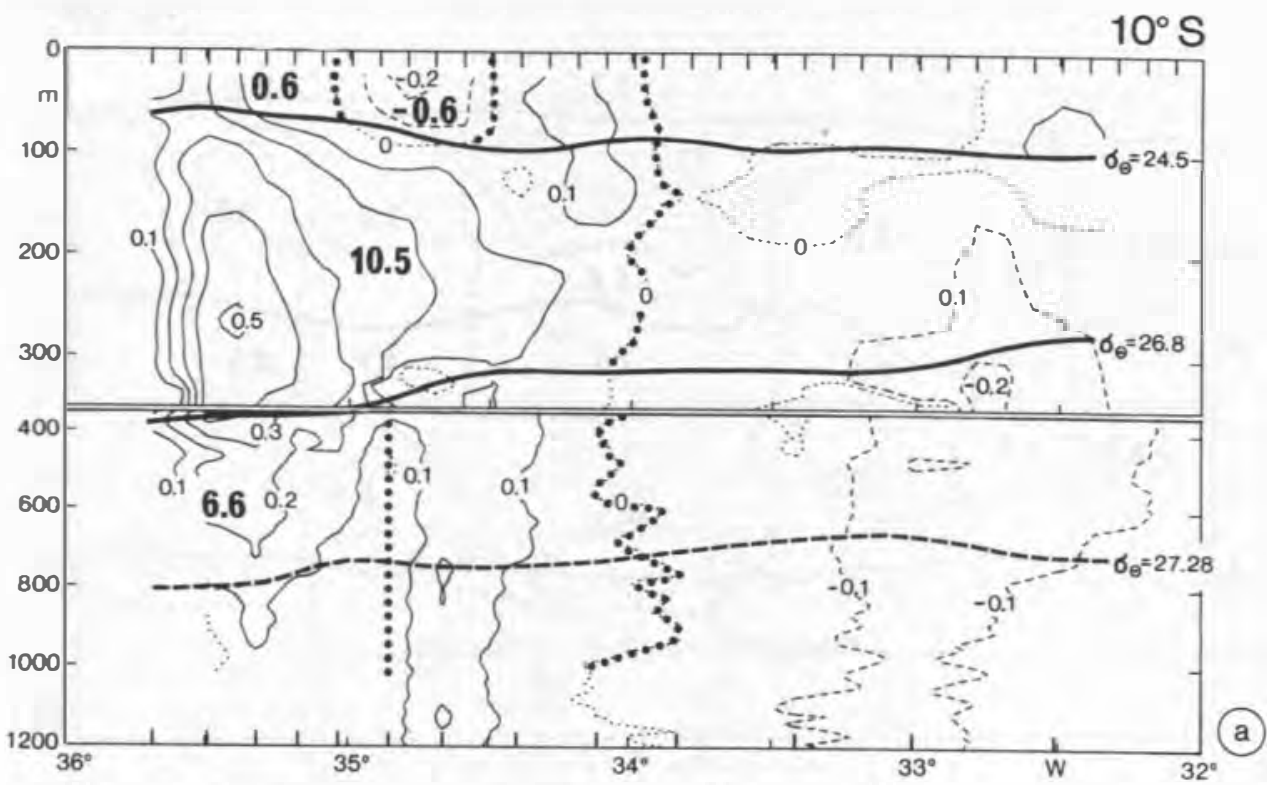

$5^{\circ} \mathrm{S}$

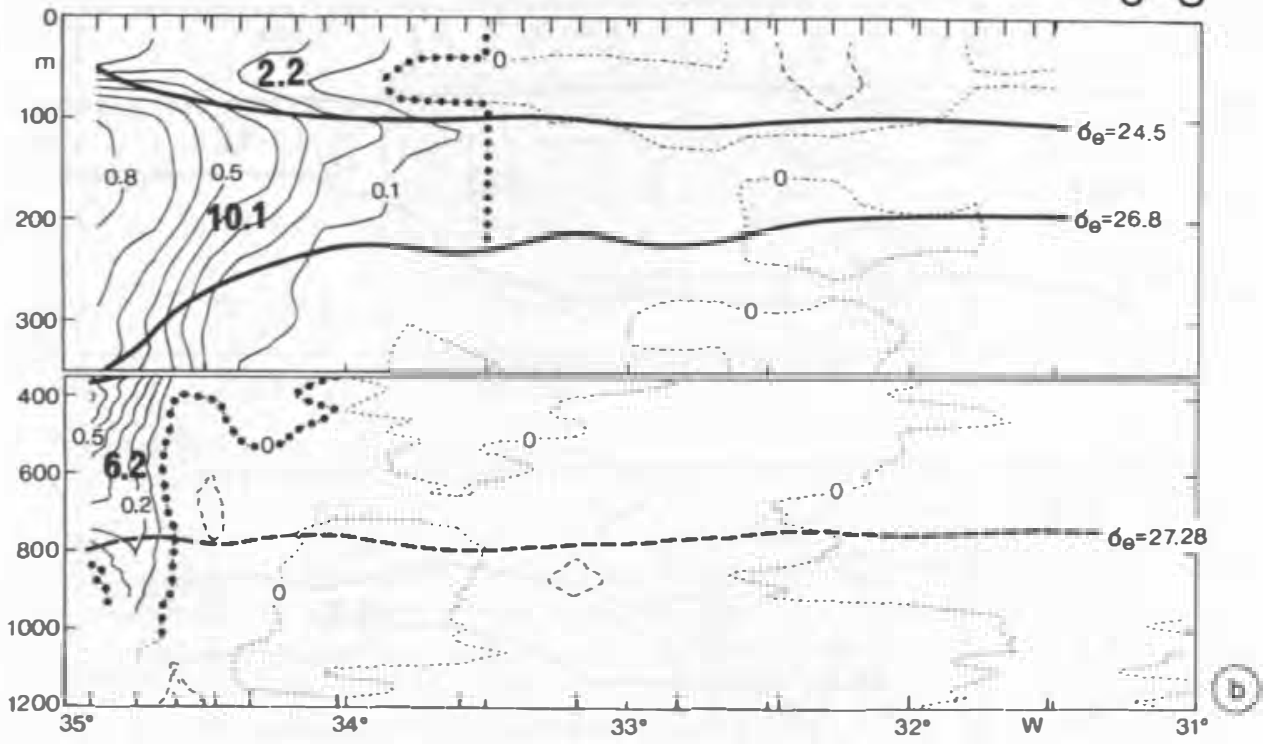

Figure 7. Current section plots in meters per second from combined shipboard and lowered ADCP of (a) meridional component at $10^{\circ} \mathrm{S}$, (b) meridional component at $5^{\circ} \mathrm{S}$, (c) zonal component at $35^{\circ} \mathrm{W}$, (d) zonal component at $40^{\circ} \mathrm{W}$, and (e) zonal component at $44^{\circ} \mathrm{W}$. Transports in sverdrups of current branches are indicated in plots (large bold numbers; I Sv $=10^{6} \mathrm{~m}^{3} \mathrm{~s}^{-1}$ ); boundaries are marked by dotted lines. Meridional transports are positive northward; zonal transports are positive eastward.

\section{Currents and Transports}

The currents of the upper $1200 \mathrm{~m}$, as measured by shipboard ADCP in the top $350 \mathrm{~m}$ and augmented by LADCP for the deeper levels, are shown in Figure 7, where LADCP data are only available for four of the five sections presented. Transport numbers for individual clearly identifiable current branches are inserted and listed in Table 1. For upper layer transports, the near-surface currents above $25 \mathrm{~m}$ were estimated by upward shear extrapolation. The isopycnals $\sigma_{\omega}=24.5$ and $\sigma_{\omega}=26.8$, which serve as layer boundaries for budget calculations later, and $\sigma_{M}=27.28$ which is the boundary for as the AAIW core, are also shown. In the following the individual current branches are discussed, and composite pictures for the three layers will be attempted.

\subsection{North Brazil Undercurrent and North Brazil Current}

At $10^{\circ} \mathrm{S}$ the NBUC current maximum with core speeds $>0.7$ $\mathrm{m} \mathrm{s}^{-1}$ (north component $>0.5 \mathrm{~m} \mathrm{~s}^{-1}$ ) lies at $250-350 \mathrm{~m}$ (Figure 7a), and at the AAIW level, speeds are still $0.2 \mathrm{~m} \mathrm{~s}^{-1}$ (Figure 7c). Hence a large transport fraction occurs below the shipboard ADCP range, and Figure 7a is augmented by LADCP measurements below $350 \mathrm{~m}$. In the near-surface layer, above $\sigma_{\omega}=24.5$, only $0.6 \mathrm{~Sv}$ flow northward, compensated by an offshore southward recirculation, and in the $\sigma_{\leftrightarrow}=24.5-26.8$ layer, which encompasses the current core, the transport amounts to $10.5 \mathrm{~Sv}$. Below $\sigma_{\Theta}=26.8$ there is still northward transport of $6.6 \mathrm{~Sv}$ near the boundary, yielding a total of 17.1 $\mathrm{Sv}$ (Table 1). However, east of $35^{\circ} \mathrm{W}$ there is a second branch of northward flow of $5.5 \mathrm{~Sv}$ below $\sigma_{+}=26.8$, and between 

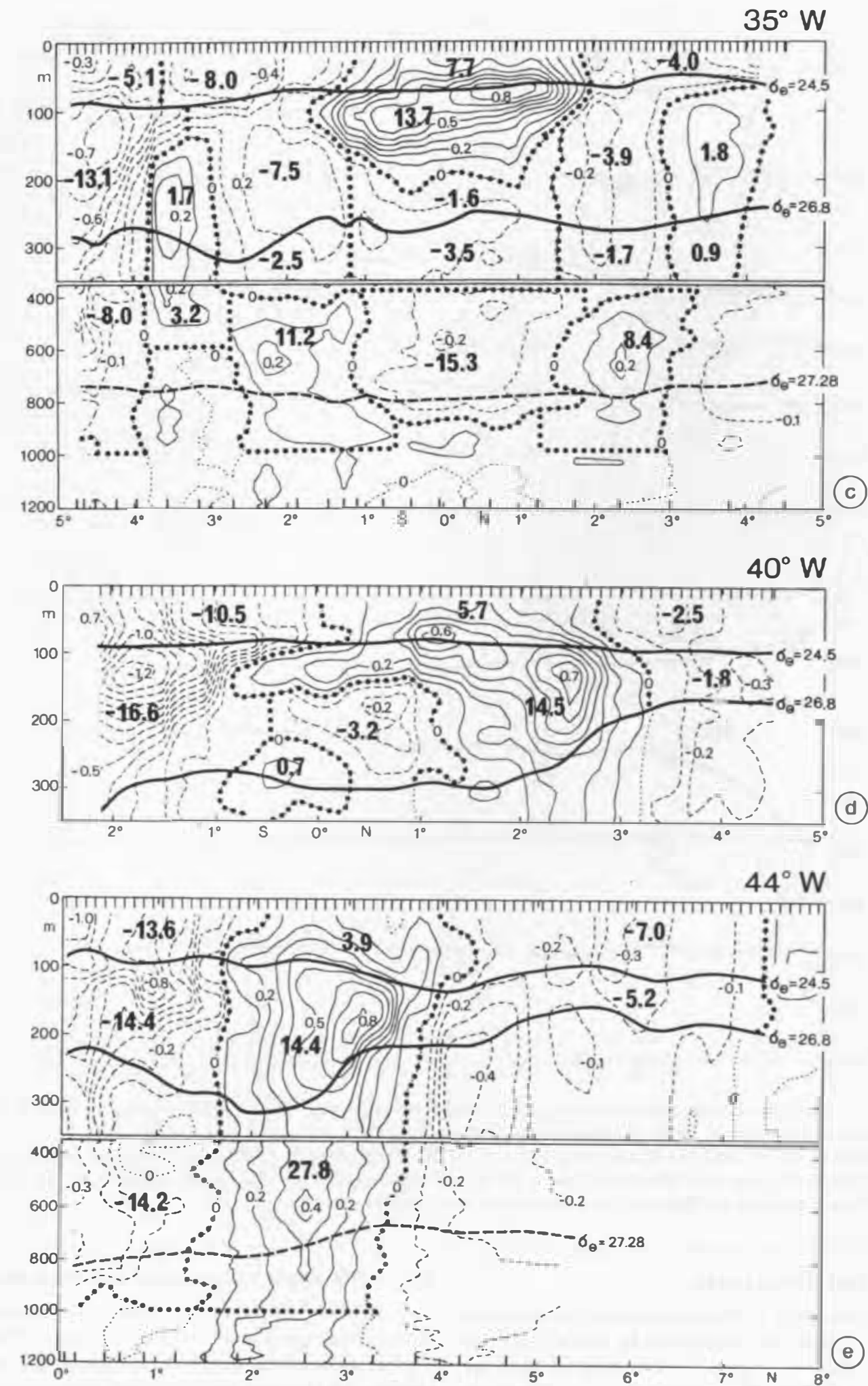

Figure 7. (continued)

$34^{\circ} \mathrm{W}$ and $32^{\circ} \mathrm{W}$, significant middepth southward flow occurs in the LADCP measurements, amounting to $13.2 \mathrm{~Sv}$ in the range, $300-1000 \mathrm{~m}$, while only to $2.0 \mathrm{~Sv}$ in the upper $300 \mathrm{~m}$. This deep flow is, however, based on only two relatively widely spaced LADCP protile , and gcostrophy yields only $2.8 \mathrm{~Sv}$ for that same segment. $i$ his middepth flow must be due to inflow from the east because as is shown below, there is near-continuity of the boundary transport between $10^{\circ} \mathrm{S}$ and $5^{\circ} \mathrm{S}$.

At $5^{\circ} \mathrm{S}$ the NBUC transport above $\sigma_{\mathrm{G}}=24.5$ has increased against the $10^{\circ} \mathrm{S}$ value, to $2.2 \mathrm{~Sv}$ (Figure 7b), but in the $\sigma_{\mathrm{H}}=$ 24.5-26.8 range there is nearly the same transport as at $10^{\circ} \mathrm{S}$ : and between $\sigma_{\Theta}=26.8$ and $1000 \mathrm{~m}$ the transport is also 
Table 1. Current Branch Transports in Western Tropical Atlantic, Spring 1994

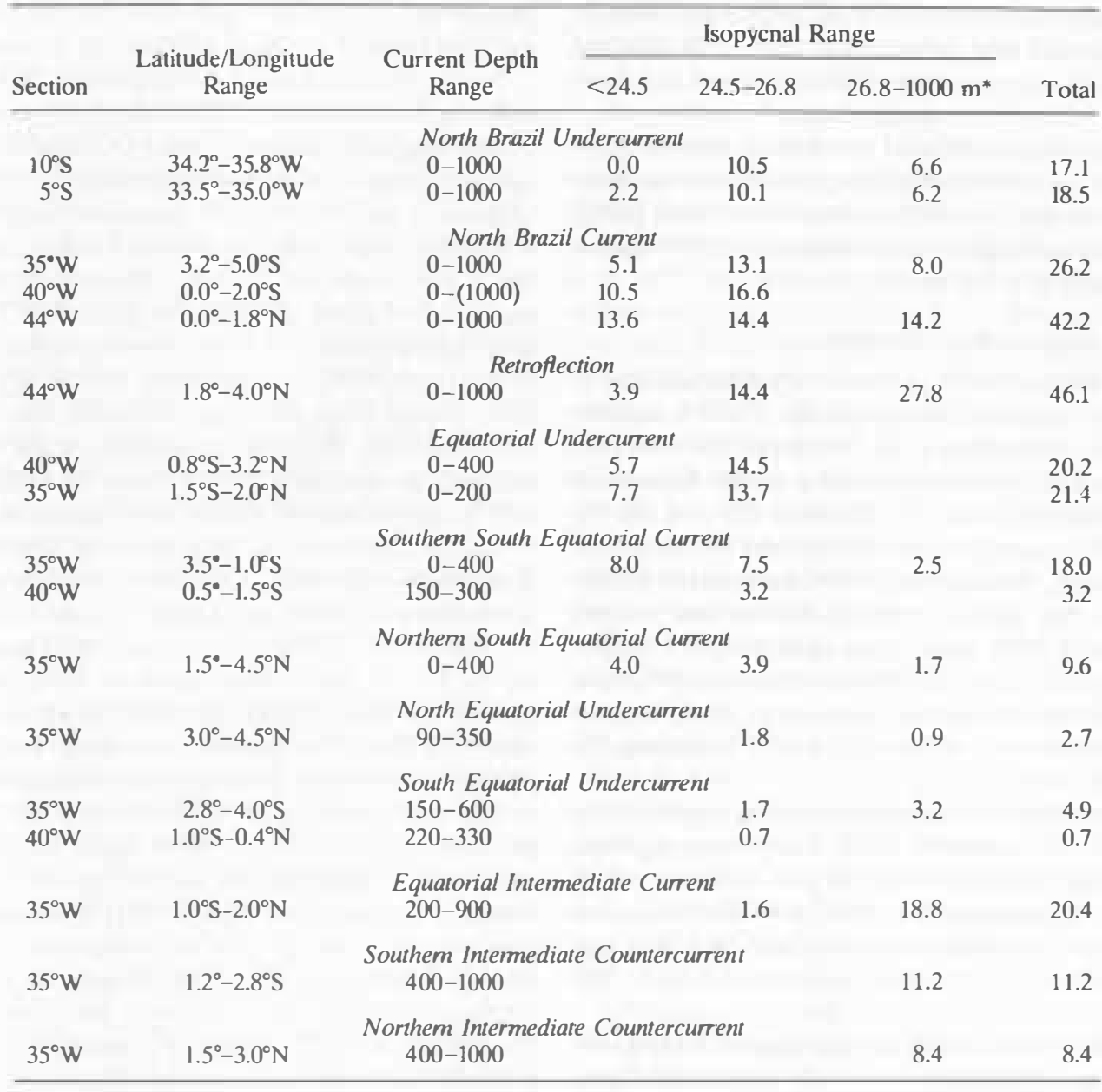

*Roughly corresponds to $\sigma_{t}=27.4$ isopycnal.

conserved against $10^{\circ} \mathrm{S}$. Overall, the total of $18.5 \mathrm{~Sv}$ for the NBUC is only $1.7 \mathrm{~Sv}$ larger than $10^{\circ} \mathrm{S}$ boundary current transport, mostly owing to an addition in the very near-surface layer. The total transport is below the 22 Sv found for November 1992 by Stramma et al. [1995], who found even less zonal inflow between $10^{\circ} \mathrm{S}$ and $5^{\circ} \mathrm{S}$. The smaller transport in austral fall is in agreement with the observations from historical hydrographic data [Stramma et al., 1995] and with the evaluation of the WOCE CME model by Schott and Böning [1991]. The winds off Brazil were from the southeast during the survey, and the corresponding Ekman transports were $0.8 \mathrm{~Sv}$ and $0.7 \mathrm{~Sv}$ southward across the $5^{\circ} \mathrm{S}$ and $10^{\circ} \mathrm{S}$ sections, respectively.

North of Cape San Roque, the westward transport increases considerably through the addition of the SEC flow. As can be seen in Figure 7c, a clear distinction between the NBUC flow arriving from the south and the SEC inflow is not possible. Taking the limit at $3.5^{\circ} \mathrm{S}$ yields a total of $18.2 \mathrm{~Sv}$ above $\sigma_{\Theta}=$ 26.8 , adding $5.9 \mathrm{~Sv}$ to what arrived above $\sigma_{\Theta}=26.8$ along the coast at $5^{\circ} \mathrm{S}$. Despite the SEC superposition, the boundary current at $35^{\circ} \mathrm{W}$ and $40^{\circ} \mathrm{W}$ (Figure $7 \mathrm{~d}$ ) maintained a subsurface maximum, while at $44^{\circ} \mathrm{W}$ the clear undercurrent character was lost (Figure 7e), in agreement with the moored ADCP observations of upper layer flow at that site by Schott et al. [1993].

Across $40^{\circ} \mathrm{W}$ the westward transport south of $1^{\circ} \mathrm{N}$ above $\sigma_{\Theta}$ $=26.8$ amounts to $27.1 \mathrm{~Sv}$, of which the llow above $\sigma_{\mathrm{G}}=24.5$ was $10.5 \mathrm{~Sv}$, and in the $\sigma_{\leftrightarrow}=24.5-26.8$ layer the flow associated with the boundary current core was $16.6 \mathrm{~Sv}$ westward, but an additional 3.2 Sv flowed westward underneath the southern part of the EUC (Figure 7d). The total flow could not be evaluated for this section because the LADCP was not functioning along $40^{\circ} \mathrm{W}$, thus limiting the measurement range to that of the shipboard ADCP.

Across $44^{\circ} \mathrm{W}$, transport is $13.6 \mathrm{~Sv}$ along the boundary and south of $2^{\circ} \mathrm{N}$ in the layer above $\sigma_{\leftrightarrow}=24.5$, and $14.4 \mathrm{~Sv}$ in the layer $\sigma_{\Theta}=24.5-26.8$ (Figure 7e), indicating a near-continuity of the boundary flow above $\sigma_{\epsilon}=26.8$ between $40^{\circ} \mathrm{W}$ and $44^{\circ} \mathrm{W}$ but with nearly compensating increase above and decrease below $\sigma_{\Theta}=24.5$. There is still a large transport across $44^{\circ} \mathrm{W}$ between $\sigma_{\mathrm{G}}=26.8$ and the $1000-\mathrm{m}$ level, amounting to $14.2 \mathrm{~Sv}$ (Figure 7e), yielding a total NBC boundary flow above $1000 \mathrm{~m}$ of $42.2 \mathrm{~Sv}$.

North of $1.5^{\circ} \mathrm{N}$, the flow is eastward up to $4^{\circ} \mathrm{N}$, with a subsurface maximum at $200 \mathrm{~m}$ (Figure 7e). This subsurface maximum also occurred in the Wilson et al. [1994] observations. While they attributed it to the NEUC for the boreal summer situation, it is dominantly a source of the EUC in our case. The eastward flow across $44^{\circ} \mathrm{W}$ in the $\sigma_{\Theta}<24.5$ layer amounts to only $3.9 \mathrm{~Sv}$, leaving a net northwestward through flow of $9.7 \mathrm{~Sv}$ along the boundary in that layer. In terms of water mass transfer, this exchange might actually be larger, if the eastward return flow were not all retroflected NBC water, but partially northern water. By contrast, there is an exact match in the 
24.5-26.8 layer between the 14.4 Sv of NBC flow and the eastward return flow. Below, between $\sigma_{\Theta}=26.8$ and $1000 \mathrm{~m}$, there is large eastward flow between $1.5^{\circ}$ and $3.5^{\circ} \mathrm{N}$, totalling $27.8 \mathrm{~Sv}$, followed by compensating westward flow of $27.7 \mathrm{~Sv}$ to the north, in the $3.5^{\circ}-5.5^{\circ} \mathrm{N}$ latitude range.

The flow budgets of the NBC and the off shore reversals have to be seen within the context of the large temporal variations observed within the NBC at $44^{\circ} \mathrm{W}$, where Schott et al. [1993] determined variations of upper layer transports of $50 \%$ against the mean at periods of a few weeks.

\subsection{The Zonal Near-Surface Currents}

As was shown for the NBUC, there is very little addition to the equatorward boundary current in the $5^{\circ}-10^{\circ} \mathrm{S}$ latitude band, amounting to less than $2 \mathrm{~Sv}$. North of $5^{\circ} \mathrm{S}$, westward surface flow was observed on both sides of the Equatorial Undercurrent (Figures $4 \mathrm{c}$ and $7 \mathrm{c}$ ). Between $5^{\circ} \mathrm{S}$ and $1^{\circ} \mathrm{S}$ the westward flow above $\sigma_{\Theta}=24.5$ was $13.1 \mathrm{~Sv}$ and $20.6 \mathrm{~Sv}$ for the $\sigma_{\Theta}=24.5-26.8$ range. Without the NBUC transport of $10.5 \mathrm{~Sv}$ above $\sigma_{\Theta}=26.8$ that arrives from the $10^{\circ} \mathrm{S}$ section, the net SEC transport across $35^{\circ} \mathrm{W}$ south of the equator is $23.2 \mathrm{~Sv}$; that is, $32 \%$ of the westward flow is of NBUC origin and $68 \%$ from the tropical interior South Atlantic. Above $\sigma_{\Theta}=24.5$, however the coastal fraction is near zero, because the $2.2 \mathrm{~Sv}$ crossing $5^{\circ} \mathrm{S}$ were already SEC inflow.

At $40^{\circ} \mathrm{W}$ the southern SEC is even less distinguishable from the coastal NBUC inflow than at $35^{\circ} \mathrm{W}$, except for a separate core of $3.2 \mathrm{~Sv}$ underneath the southern part of the retroflection. In terms of composition of the NBC at $44^{\circ} \mathrm{W}, 70 \%$ of it is of southern coastal origin in the isopycnal range $24.5-26.8$, and of the 13.6 Sv above $\sigma_{\Theta}=24.5,84 \%$ is of low-latitude $\left(<5^{\circ} \mathrm{S}\right)$ origin.

A southern hemispheric zonal current reported earlier by Molinari [1982] was the existence of a South Equatorial Countercurrent at $25^{\circ}$ to $30^{\circ} \mathrm{W}$, a band of eastward flow between $7^{\circ}$ and $9^{\circ} \mathrm{S}$. As can be seen from the current vector map in Figure $4 \mathrm{c}$ as well as from the transport budgets, such a current was not observed during the March 1994 survey west of $30^{\circ} \mathrm{W}$.

Across the $35^{\circ} \mathrm{W}$ section, between $1.5^{\circ} \mathrm{N}$ and $4.5^{\circ} \mathrm{N}$, westward SEC transports of $4.0 \mathrm{~Sv}$ were determined above $\sigma_{\Theta}=$ 24.5 and 3.9 Sv at $\sigma_{\Theta}=24.5-26.8$, within which the NEUC is embedded (Figure 7c). In northern summer the northern part of that section would show vigorous eastward surface currents as part of the North Equatorial Countercurrent, but in March the NECC is weak or even reversed, as was found in our observations. In the $40^{\circ} \mathrm{W}$ section the northern SEC is found north of $2.5^{\circ} \mathrm{N}$, transporting about half of the $35^{\circ} \mathrm{W}$ volume above $\sigma_{\Theta}=26.8$. There is a net outflow to the north across the $4^{\circ} 30^{\prime} \mathrm{N}$ section, amounting to $5.7 \mathrm{~Sv}$ above $\sigma_{\circledast}=26.8$, that is, larger than the difference between both zonal transports. At $44^{\circ} \mathrm{W}$, the westward SEC-NECC transport amounts to $12.2 \mathrm{~Sv}$ above $\sigma_{\Theta}=26.8$ south of $7^{\circ} 30^{\prime} \mathrm{N}$ (Figure 7e).

At $44^{\circ} \mathrm{W}$ the zonal SEC and NECC westward inflow plus the excess of the NBC over the retroflection return flow lead to a net westward flow between the coast and $7^{\circ} \mathrm{N}$ of $16.7 \mathrm{~Sv}$ above $\sigma_{\Theta}=24.5$ and $5.2 \mathrm{~Sv}$ in the second layer.

\subsection{The Equatorial Undercurrents}

The survey fell into the time period of near-equatorial location of the intertropical convergence zone. During the passage along the $35^{\circ} \mathrm{W}$ section, winds on the equator were unsteady, though generally eastward. As a consequence, the EUC in spring is nearer to the surface than in fall in the western
Atlantic, and eastward winds at times cause an eastward surface jet [e.g., Richardson and Reverdin, 1987; Schott and Böning, 1991] similar to the semiannual jet in the Indian Ocean.

During M27, equatorial currents along $35^{\circ} \mathrm{W}$ were eastward between the surface and $200 \mathrm{~m}$ with a total transport of $21.4 \mathrm{~Sv}$. At this longitude, the core of the EUC was located north of the equator owing to its northern hemispheric retroflection source (Figures $4 \mathrm{c}$ and $7 \mathrm{c}$ ). At $40^{\circ} \mathrm{W}$, the equatorial eastward flow had a complex shape with two eastward cores, centered at $1.2^{\circ} \mathrm{N}$ and $2.5^{\circ} \mathrm{N}$, respectively. The undercurrent transport below $\sigma_{\Theta}=24.5$ of about $14.5 \mathrm{~Sv}$ is the same at $44^{\circ} \mathrm{W}$ and $40^{\circ} \mathrm{W}$ and only slightly lower, at $13.7 \mathrm{~Sv}, 550 \mathrm{~km}$ farther east, when that flow crosses $35^{\circ} \mathrm{W}$. Overall, based only on the transports, the EUC supply in its core layer is totally out of the southem hemisphere via the NBC retroflection at the western equatorial end, as was already suggested by Metcalf and Stalcup [1967], on the basis of oxygen distributions alone.

Underneath the EUC the presence of the westward flowing Equatorial Intermediate Current was established in repeat sections across the equatorial Pacific. A band of westward flow is also obvious at $35^{\circ} \mathrm{W}$ in our observations (Figure 7c). Evidence of the EIC in the Atlantic exists at least since 1963, when Stalcup and Metcalf [1966] observed steady westward currents below the EUC. The measurements were obtained from shortduration (6-60 days) current meter moorings near the equator at $35^{\circ} \mathrm{W}$ and farther east. While this flow was not called EIC, the authors noted "that, at $405 \mathrm{~m}$ depth, the westward current appears to be concentrated at the Equator." The name EIC was used by Hisard and Rual [1970] for the description of the observations in the Atlantic by Stalcup and Metcalf [1966]. In our observation, the EIC transport between $1^{\circ} \mathrm{S}$ and $2^{\circ} \mathrm{N}$ and for the depth range $200-1000 \mathrm{~m}$, is quite large, at $20.4 \mathrm{~Sv}$. In the Pacific, at $165^{\circ} \mathrm{W}$, mean EIC transports were only $4.5 \mathrm{~Sv}$ [Gouriou and Toole, 1993]. Hence our individual estimate may just be one view of a time-varying deep current system on the equator that shows strong variability at periods of weeks to months as found in the moored deep records of Schott et al. [1993] and as also seen in recently retrieved current meter records from a station deployed on the equator at $37^{\circ} \mathrm{W}$.

\subsection{The Off-Equatorial Undercurrents}

The core of the SEUC, between $3^{\circ}$ and $4^{\circ} \mathrm{S}$ and at depths of $150-600 \mathrm{~m}$, and that of the NEUC, between $3^{\circ}$ and $4^{\circ} \mathrm{N}$ and at 90-350 m, are recognizable in the $35^{\circ} \mathrm{W}$ section (Figure 7c). Transport of the SEUC was $4.9 \mathrm{~Sv}$, with only $1.7 \mathrm{~Sv}$ above $\sigma_{\theta}=26.8$, and for the NEUC the total transport was $2.7 \mathrm{~Sv}$, of which $1.8 \mathrm{~Sv}$ fell into the $\sigma_{\oplus}<26.8$ range. However, it has to be noted that LADCP station spacing below $300 \mathrm{~m}$ was not adequate for these narrow currents. While isopycnal maps of Tsuchiya [1986] for oxygen and salinity show maxima extending eastward at the latitudes of the SEUC and NEUC, connecting their water mass properties to the NBC, such connection is not obvious from our measurements. In fact, the oxygen and salinity at the SEUC core resemble much more the interior tropical environment than the high values of $>4 \mathrm{~mL} \mathrm{~L}^{-1}$ and $<35.0$ typical for the NBUC (Figures 3 and 5). This suggests supply through recirculation rather than via NBUC retroflection. In the southern part of the $40^{\circ} \mathrm{W}$ section a small core near $\sigma_{\Theta}=26.8$ can be identified in Figure 7d, embedded in the westward SEC flow. This suggests the root of the SEUC to be as far west as $40^{\circ} \mathrm{W}$.

For the NEUC, partial supply could split off from the northern part of the NBC retroflection, as water masses show south- 
ern properties at some observation points in the western NEUC region (Figure 5c). However, the NEUC at $35^{\circ} \mathrm{W}$ appears more dominated by low-oxygen equatorial waters (Figure $3 b)$ than southern waters.

At intermediate depths, the Northern and Southern Intermediate Countercurrents are seen at $35^{\circ} \mathrm{W}$ in the depth range 400-900 $\mathrm{m}$ (Figure 7c). The SICC between 1.2 and $2.8^{\circ} \mathrm{S}$ carries $11.2 \mathrm{~Sv}$, while the NICC, between $1.5^{\circ}$ and $3.0^{\circ} \mathrm{N}$, transports $8.4 \mathrm{~Sv}$. For comparison, in the Pacific at $159^{\circ} \mathrm{W}$ the SICC mean was determined to $8.7 \mathrm{~Sv}$, and the NICC mean was determined to be $3.0 \mathrm{~Sv}$ [Firing, 1987].

As can be seen in the water mass distribution along $35^{\circ} \mathrm{W}$ (Figure 3 ) and the distributions on $\sigma_{\Theta}=27.28$, the SICC is characterized by high oxygen values and low salinities, relating it to AAIW waters in the deeper part of the NBUC. At the location of the NICC axis, by contrast, salinities are higher and oxygen values are lower than in the NBUC, indicating that its supply is dominantly of northern origin and out of recirculation of the EIC, but admixtures of NBUC water are suggested by the meridional property gradients across the NICC (Figures 3 and 6 ).

The reconciliation of the deep zonal transports with those crossing $44^{\circ} \mathrm{W}$ is not straightforward. At $44^{\circ} \mathrm{W}$ the deep eastward flow out of the retroflection at $1.5^{\circ}-3.5^{\circ} \mathrm{N}$ carries $27.8 \mathrm{~Sv}$ below $\sigma_{\Theta}=26.8$. If that supplies the NICC in about the same latitude range, there is $7 \mathrm{~Sv}$ of net eastward inflow into the $35^{\circ}-44^{\circ} \mathrm{W}$ longitude range and south of $4^{\circ} \mathrm{N}$ left from the west. An attempt to compose a consistent flow pattern on the basis of transports and water masses will be presented at the end of the paper.

\subsection{Antarctic Intermediate Water Transport}

The AAIW is clearly identifiable in the water mass distributions by its salinity minimum (Figures 3 and 6 ). In the currents the AAIW depth range is part of the downward decaying NBUC profiles, and there is no secondary velocity maximum associated with it in the sections at $10^{\circ} \mathrm{S}$ (Figure $7 \mathrm{a}$ ) or $5^{\circ} \mathrm{S}$ (Figure 7b). Limiting the AAIW by the $\sigma_{\Theta}=26.8$ and $\sigma_{\leftrightarrow}=$ 27.4 levels [e.g., Roemmich, 1983], which would put the lower limit near $1000-\mathrm{m}$ depth, would yield an incoming transport into the equatorial regime of $6.0 \mathrm{~Sv}$. Putting the upper level at $\sigma_{\omega}=27.1$, the boundary between the South Atlantic Central Water and AAIW, and the lower level at $\sigma_{1}=32.15$, following Stramma et al. [1995], results in a slightly larger number, $6.8 \mathrm{~Sv}$, at $10^{\circ} \mathrm{S}$. As to the further fate of the AAIW, the LADCP data are too sparse to determine it, but there is a continuity of the deep NBUC and NBC from $10^{\circ} \mathrm{S}$ to the equator along the boundary (Figure 7c), and salinity minimum water is observed in the Caribbean and Florida Current [Tsuchiya, 1986; Schmitz and Richardson, 19911. Part of the AAIW enters the SICC as indicated by the low-salinity and high-oxygen core at $\sigma_{\leftrightarrow}=$ 27.28 along $2^{\circ} \mathrm{S}$ (Figure 6). The meridional gradients of both, salinity and oxygen across the latitude band occupied by the NICC (Figures 3 and 6) suggest admixtures of AAIW contributions to waters of northem origin or out of the recirculation from the EIC. Both the SICC and NICC transports as well as the deep NBC along $44^{\circ} \mathrm{W}$ are larger than the AAIW inflow at $I 0^{\circ} \mathrm{S}$; hence the AAIW can make up only a small fraction of the deep off-equatorial countercurrents.

\section{Summary and Conclusions}

In a survey with CTD and current-profiling methods during spring 1994 , the boundary current between $10^{\circ} \mathrm{S}$ and $10^{\circ} \mathrm{N}$ of the western tropical Atlantic was investigated, and an attempt was made to budget the warm water routes that carry southern hemispheric waters toward the equator and of their coupling to the zonal equatorial circulation.

The vertical structure of the northward boundary current along the Brazilian coast between $5^{\circ}$ and $10^{\circ} \mathrm{S}$ is that of an undercurrent with the current core of $80 \mathrm{~cm} \mathrm{~s}^{-1}$ at about 200- $\mathrm{m}$ depth and small near-surface currents. This structure was also found in earlier surveys [Silveira et al., 1994; Stramma et al., 1995] and is also reproduced in a high-resolution numerical model [Schott and Böning, 1991]. Part of the reason for the existence of this structure, which has its equivalent in the New Guinea Undercurrent in the western tropical Pacific [Lindstrom et al., 1987; Tsuchiya et al., 1989], could be the fact that the Ekman transport in the western tropical region of both oceans is directed against the geostrophic flow, leading to the typical dynamics of an upwelling regime with a poleward surface pressure gradient which is compensated by an equatorward subsurface pressure gradient that then causes an equatorward subsurface current.

The transport budgeting for the different current branches was carried out between isopycnal layers; for the near-surface layer above $\sigma_{\boldsymbol{\Theta}}=24.5$, for the undercurrent layer in the isopycnal range $\sigma_{\Theta}=24.5-26.8$, and for the Antarctic Intermediate Water layer between $\sigma_{\Theta}=26.8$ and $1000 \mathrm{~m}$, which corresponds roughly to $\sigma_{\Theta}=27.4$ in the region. Despite careful calibration of the decomposition of the shipboard ADCP currents, significant errors can arise from small compass misalignment residuals. This effect is of course most severe for the weaker offshore currents that require integration over long stretches of ship track.

In the equatorial regime there is a further difficulty for mean current and transport determination, the presence of an energetic field of equatorial waves of periods ranging from weeks to months in the region [e.g., Weisberg and Weingartner, 1988; Schott et al., 1993]. It prohibits the application of equatorial geostrophy unless averaged over a sufficient number of sections and may also be responsible for a fair part of the transport discrepancies found in our study.

In the near-surface layer the inflow stems dominantly from low latitudes (Figure $8 \mathrm{a}$ ). At $10^{\circ} \mathrm{S}$, there is no net transport along the boundary, and between $10^{\circ}$ and $5^{\circ} \mathrm{S}$ only $2 \mathrm{~Sv}$ flow in from the east. However between $5^{\circ} \mathrm{S}$ and $1^{\circ} \mathrm{S}$ the SEC transports $11 \mathrm{~Sv}$ westward into the region. Hence $13 \mathrm{~Sv}$ leave the $35^{\circ} \mathrm{W}$ section westward, and $14 \mathrm{~Sv}$ arrive at $44^{\circ} \mathrm{W}$. However, only $11 \mathrm{~Sv}$ cross the $40^{\circ} \mathrm{W}$ meridian. While the decrease from $35^{\circ} \mathrm{W}$ to $40^{\circ} \mathrm{W}$ could be explained by recirculation into the shallow EUC, the increase from $40^{\circ} \mathrm{W}$ to $44^{\circ} \mathrm{W}$ is hard to explain; it cannot come from the eastward retroflection flow because there is an eastward increase of $2 \mathrm{~Sv}$, not decrease in that branch between $44^{\circ} \mathrm{W}$ and $40^{\circ} \mathrm{W}$. The total gain of the upper layer between $40^{\circ} \mathrm{W}$ and $44^{\circ} \mathrm{W}$ was $5 \mathrm{~Sv}$, almost compensated by a deficit of the same magnitude for the layer below; we come back to this point below. North of the EUC, transports are westward, with $4 \mathrm{~Sv}$ arriving across $35^{\circ} \mathrm{W}$, south of $4.5^{\circ} \mathrm{N}$. Farther north, another $3 \mathrm{~Sv}$ join to make the total transport $7 \mathrm{~Sv}$ that crosses $44^{\circ} \mathrm{W}$ above $\sigma_{\Theta}=24.5$ (Figure $8 \mathrm{a}$ ). Hence in agreement with earlier studies of drifters [Richardson and Walsh, 1986], there is no eastward flow at this time of year in the latitudinal band usually occupied by the NECC.

The transport difference between the westward NBC flow across $44^{\circ} \mathrm{W}$ and the eastward flow offshore is $10 \mathrm{~Sv}$ above $\sigma_{\Theta}=24.5$. This is through flow of southern hemispheric water 

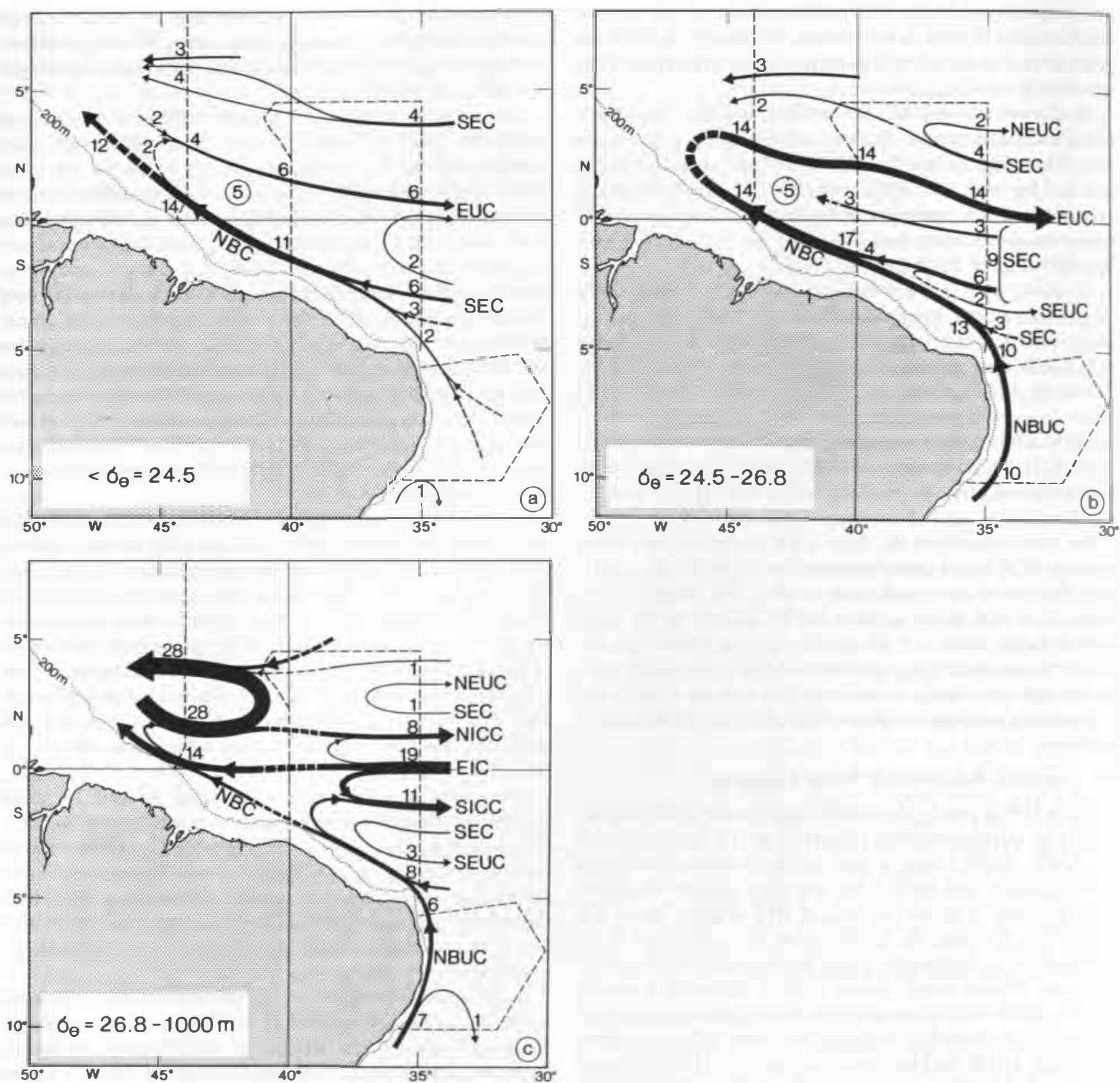

Figure 8. Composite transport scheme for the circulation in isopycnic layers: (a) surface to $\sigma_{\Theta}=24.5$, (b) $\sigma_{\epsilon}=24.5-26.8$, and (c) $\sigma_{\epsilon}=26.8-1000 \mathrm{~m}\left(1000 \mathrm{~m}\right.$ roughly corresponding to $\left.\sigma_{\Theta}=27.4\right)$. Transports were rounded to sverdrups, imbalances are shown in circles (see also Table 1).

toward the Caribbean. Since there is no identifiable significant eastward return flow across our section even farther north than $7^{\circ} \mathrm{N}$, this flow did apparently continue northwestward along the boundary in spring 1994. The $10 \mathrm{~Sv}$ of through flow is a lower limit, obtained when assuming that all of the $4 \mathrm{~Sv}$ of the eastward counterflow offshore (Figure $8 a$ ) is retroflected water. However, part of it has to be northern water as shown by the water masses on $\sigma_{\Theta}=25.0$ (Figure 4). In the schematic graph we acknowledge this partition by counting only half of the $4 \mathrm{~Sv}$ of eastward flow across $44^{\circ} \mathrm{W}$ as retroflection water, bringing the total through flow above $\sigma_{\Theta}=24.5$ to $12 \mathrm{~Sv}$.

For the undercurrent layer (Figure $8 b$ ), the low-salinity, high-oxygen source waters originate dominantly from latitudes exceeding $10^{\circ} \mathrm{S}$ : $10 \mathrm{~Sv}$ arrived as boundary llow in the NBUC and were only marginally augmented from the east in the $10^{\circ}-5^{\circ} \mathrm{S}$ latitude range. Within the SEC, $3 \mathrm{~Sv}$ join the NBC at $35^{\circ} \mathrm{W}$ just north of $5^{\circ} \mathrm{S}$, while $9 \mathrm{~Sv}$ of high-salinity, low-oxygen waters joined from the east in this layer, including the $2 \mathrm{~Sv}$ below the EUC (Figure 7c). There are also inconsistencies in the transport budgets for this layer between $40^{\circ} \mathrm{W}$ and $44^{\circ} \mathrm{W}$. It can be stated that $14 \mathrm{~Sv}$ arrive at $44^{\circ} \mathrm{W}$ and that there is matching eastward transport in the off shore flow that continues at about the same amount over the $1000-\mathrm{km}$ distance to the $35^{\circ} \mathrm{W}$ section. The transport agreement, combined with the southern water mass properties of that flow indicate that the 14 Sv of EUC flow in the $\sigma_{\Theta}=24.5-26.8$ layer are fed out of the boundary flow and that $10 \mathrm{~Sv}$ of it originate from farther south than $10^{\circ} \mathrm{S}$. The total EUC transport of $21.4 \mathrm{~Sv}$ at $35^{\circ} \mathrm{W}$ in March 1994 is in good agreement with the model results and direct observation at this season [Schott and Böning, 1991, Figure 8]. 
The transport inconsistency in the NBC between $40^{\circ} \mathrm{W}$ and $44^{\circ} \mathrm{W}$ also applies to the undercurrent layer; here there is an unexplained decrease of $5 \mathrm{~Sv}$ (Figure 8b; Table 1) between both longitudes, while in the upper layer there was an increase of $5 \mathrm{~Sv}$. Although measurement errors may account for 1-2 Sv in the main current branches, it can almost be excluded that they were responsible for these inconsistencies. The main source of errors were GPS navigation and compass inaccuracies, both of which are not depth dependent and therefore could not explain the sign change of the transport inconsistencies between the layers. Upper layer transports also depend on how representative the shear extrapolation over the top $25 \mathrm{~m}$ was, but again this could not explain the sign change of the transport imbalance. This leaves three possible reasons for these (and other) discrepancies in both layer transports: First, the surface mixed layer in the northwestern part of the survey region reached down very closely to the level $\sigma_{\Theta}=24.5$, meaning that mass was probably not fully conserved in each of the layers. This, together with the downstream rise of the NBC and EUC cores suggests that upwelling might play a role, leading to some exchange between the two layers. Second, nonsynopticity of the survey was certainly a factor, and third, flow could escape onto the wide shelf region at $40^{\circ} \mathrm{W}$ and $44^{\circ} \mathrm{W}$, but not at $35^{\circ} \mathrm{W}$. In October 1992 and in June 1991 the transport over the shelf at $44^{\circ} \mathrm{W}$ was only about $0.5 \mathrm{~Sv}$ [Schott et al., 1993], while Candela et al. [1992] obtained 3.0 Sv in May and March from $\mathrm{ADCP}$ sections farther northwest at $48^{\circ}-52^{\circ} \mathrm{W}$.

As regards the off-equatorial North and South Equatorial Undercurrents, the water masses show clearly for the SEUC and not quite so clearly for the NEUC that they do not originate out of the boundary current but instead originate from recirculation of low-oxygen equatorial waters [Tsuchiya, 1986], and we mark them correspondingly in Figure $8 \mathrm{~b}$. The situation for the NEUC was found different from our observations for the summer circulation [Wilson et al., 1994], when the NECC is fully developed and not flowing westward as during our survey. The transport of the SEUC of $4.9 \mathrm{~Sv}$ at $35^{\circ} \mathrm{W}$ is small compared with the mean geostrophic transport of $15 \mathrm{~Sv}$ by $\mathrm{Co}$ chrane et al. [1979], which in part may result from their measurement locations further east. Molinari [1982] described a range between 5 and $23 \mathrm{~Sv}$ for the SEUC also further east, at $25^{\circ}$ to $28^{\circ} \mathrm{W}$.

The Antarctic Intermediate Water inflow below $\sigma_{\Theta}=26.8$ that arrived in the region as the deep part of the NBUC had a transport of $6 \mathrm{~Sv}$ at $10^{\circ} \mathrm{S}$ and $5^{\circ} \mathrm{S}$. That number is lower than the $10 \mathrm{~Sv}$ obtained in inverse calculations for the Tropical Atlantic at $8^{\circ} \mathrm{S}$ by Roemmich [1983] and the 8-14 Sv obtained by Schlitzer [1988] while in agreement with inverse results obtained by $F u[1981]$ using International Geophysical Year data from the subtropical South Atlantic. This flow turns around Cape San Roque (Figure 8c), and then there appears to be interaction with the two deep off-equatorial undercurrents, the Southern and Northern Intermediate Countercurrents. The SICC in particular is clearly related, by its high oxygen values and low salinities (Figure 6), to the AAIW in the boundary current. For the NICC the sources appear dominantly northern and out of the recirculation of equatorial waters, but admixtures of AAIW are suggested by a slight oxygen maximum off shore in the $44^{\circ} \mathrm{W}$ section, (Figure 6b). Other presentations of AAIW level distributions [Le Floc'h and Merle, 1975] indicate a branching of the AAIW eastward south of the equator by an eastward extending oxygen maximum and salinity mini- mum while showing no such eastward extension at the NICC latitude [T suchiya, 1989].

The transports for the SICC and NICC are quite large, at 11 and $8 \mathrm{~Sv}$, respectively. Wedged in between the NICC and SICC is the westward flowing Equatorial Intermediate Current. While the NICC and SICC were not previously reported to exist in the Atlantic, the EIC was already documented in the observations of Stalcup and Metcalf [1966] and Hisard and Rual [1970], although transports could not be determined in these earlier measurements. In our section that EIC transports $19 \mathrm{~Sv}$ westward between $\sigma_{\Theta}=26.8$ and $1000 \mathrm{~m}$, part of which recirculates into the SICC and NICC and part of which continues to merge with the NBC yielding a cross-equational flow of $14 \mathrm{~Sv}$ at $44^{\circ} \mathrm{W}$. Although the transports in that layer nearly balance in the $35^{\circ} \mathrm{W}$ section, one has again to keep aware of the equatorial wave system that can overlay small mean currents in the directly measured current profiles. Hence we present these numbers for the equatorial intermediate currents as first indications, not more.

The equatorial divergence in the Atlantic amounts to an upwelling of about $25 \mathrm{~Sv}$ that needs to be compensated by subsurface (above $\sigma_{\omega}=26.8$ ) geostrophic flow toward the equator [e.g., Roemmich, 1983]. Between our $44^{\circ} \mathrm{W}$ and $35^{\circ} \mathrm{W}$ sections, we could not detect the upwelling, for example, by a rising of the subsurface salinity maximum across isopycnal surfaces, although the water mass transfer of $5 \mathrm{~Sv}$ indicates some upwelling. In terms of the overall warm water transport the three layers show (Figures $7 \mathrm{a}$ and $7 \mathrm{~b}$ ) that $16 \mathrm{~Sv}$ arrive from the south along the coast, about the right number for the Atlantic overturning cell [e.g., Roemmich and Wunsch, 1985; Rintoul, 1991]. The low-latitude inflow into the western boundary regime that is added to the boundary flow north of $5^{\circ} \mathrm{S}$ (by the SEC) must then dominantly be recirculation of equatorial water, stemming from the equatorial divergence, out of the EUC rather than a "detour branch" of the "conveyor belt" circulation. This is clearly supported by the difference in the water mass properties of the SEC and NBUC branches.

Acknowledgments. We thank D. Kindler for help in the data processing and A. Eisele for the drafting. We further thank Y. Gouriou for detailed comments and for pointing out early sources of the EIC. Meteor cruise M27 was supported by Deutsche Forschungsgemein schaft, and the western tropical Atlantic work was supported under the German WOCE program by the Bundesministerium für Bildung, Wissenschaft, Forschung, und Technologie, grant 3F01212A.

\section{References}

Arnault, S., Tropical Atlantic geostrophic currents and ship drifts, $J$ Geophys. Res., 92, 5076-5088, 1987.

Candela, J., R. C. Beardsley, and R. Limeburner, Separation of tida and subtidal currents in ship-mounted acoustic Doppler current profiler observations, J. Geophys. Res., 97, 769-788, 1992

Cischrane, J. D., F. J. Kelly Jr., and C. R. Olling, Subthermocline countercurrents in the western equatorial Atlantic Ocean, J. Phys. ()eanogr., 9, 724-738, 1979.

Didden, N., and F. Schott, Seasonal variations in the western tropical Atlantic: Surface circulation from Geosat altimetry and WOCE model results, J. Geophys. Res., 97, 3529-3541, 1992.

Didden, N., and F. Schott, Eddies in the North Brazil Current retroflection region obscrved by Geosat altimetiy, J. Geophys. Res., 98. 20,121-20,131, 1993.

Emery, W. J., and J. Meincke, Global water masses: Summary and review, Oceanol. Acta, 9, 383-391, 1986.

Fischer, J., and M. Visbeck, Deep velocity profiling with self-contained ADCPs, J. Atmos. Oceanic Technol., In, 764-77.3, 199.3. 
Firing, E., Deep zonal currents in the central equatorial Pacific, J. Mar. Res., 45, 791-812, 1987.

Fu, L.-L., The general circulation and meridional heat transport of the subtropical South Atlantic determined by inverse methods, J. Phys. Oceanogr., 11, 1171-1193, 1981.

Gouriou, Y., and J. Toole, Mean circulation of the upper layers of the western equatorial Pacific Ocean, J. Geophys. Res., 98, 22,49522,520, 1993.

Hisard, P., and P. Rual, Courant équatorial intermédiaire de l'océan Pacifique et contre-courants adjacents, Cah. ORSTOM., Ser., Ocean$o g r$. 8, 21-45, 1970.

Johns, W. E., T. N. Lee, F. Schott, R. Zantopp, and R. Evans, The North Brazil Current retroflection: Seasonal structure and eddy variability, J. Geophys. Res., 95, 22,103-22,120, 1990.

Le Floc'h, J., and J. Merle, Les eaux intermediaires Antarctiques dans l'Atlantique intertropical, Cah. ORSTOM, ser. Oceanogr., 13, 217237, 1975.

Lindstrom, E., R. Lukas, R. Fine, E. Firing, S. Godfrey, G. Meyers, and M. Tsuchiya, The western equatorial Pacific Ocean circulation study, Nature, 330, 533-537, 1987.

Metcalf, W., and M. Stalcup, Origin of the Atlantic Equatorial Undercurrent, J. Geophys. Res., 72, 4959-4975, 1967.

Molinari, R. L., Observations of eastward currents in the tropical South Atlantic Ocean: 1978-1980, J. Geophys. Res., 87, 9707-9714, 1982.

Molinari, R. L., and E. Johns, Upper layer temperature structure of the western tropical Atlantic, J. Geophys. Res., 99, 18,225-18,233, 1994.

Miiller-Karger, F. E., C. R. McClain, and P. L. Richardson, The dispersal of Amazon's water, Nature, 333, 56-59, 1988.

Pollard, R. T., and J. Read, A method for calibrating ship-mounted acoustic Doppler current profilers, and the limitations of gyrocompasses, J. Atmos. Oceanic Technol., 6, 859-865, 1990.

Reid, J. L., On the total geostrophic circulation of the South Atlantic Ocean: Flow patterns, tracers, and transports, Prog. Oceanogr., 23, 149-244, 1989.

Richardson, P. L., and S. G. H. Philander, The seasonal variations of surface currents in the tropical Atlantic Ocean: A comparison of ship drift data with results from a general circulation model, J. Geophys. Res., 92, 715-724, 1987.

Richardson, P. L., and G. Reverdin, Seasonal cycle of velocity in the Atlantic North Equatorial Countercurrent measured by surface drifters, current meters, and ship drifts, J. Geophys. Res., 92, 36913708, 1987.

Richardson, P. L., and W. J. Schmitz Jr., Deep cross-equatorial flow in the Atlantic measured with SOFAR floats, J. Geophys. Res., 98, 8371-8387, 1993.

Richardson, P. L., and D. Walsh, Mapping climatological seasonal variations of surface currents in the tropical Atlantic using ship drift data, J. Geophys. Res., 91, 10.537-10,550, 1986.

Richardson, P. L., G. E. Hufford, R. Limeburner, and W. S. Brown, North Brazil Current retroflection eddies.J. Geophys. Res., 99, 50815093,1994
Rintoul, S., South Atlantic interbasin exchange, J. Geophys. Res., 96, 2675-2692, 1991.

Roemmich, D., The balance of geostrophic and Ekman transports in the tropical Atlantic Ocean, J. Phys. Oceanogr., 13, 1534-1539, 1983.

Roemmich, D., and C. Wunsch, Two transatlantic sections: Meridional circulation and heatflux in the subtropical North Atlantic Ocean Deep Sea Res., 32, 619-664, 1985.

Romaneessen, E., Untersuchungen saisonaler Variabilität im südlichen äquatorialen Atlantik und der Karibik mit Geosat, Diplomarbeit, Univ. Kiel, Kiel, Germany, 1993.

Schlitzer, R., Modeling the nutrient and carbon cycles of the North Atlantic, 1, Circulation, mixing coefficients, and heat fluxes, J. Geophys. Res., 93, 10,699-10,723, 1988.

Schmitz, W. J., Jr., and P. L. Richardson, On the sources of the Florida Current, Deep Sea Res., 38, suppl. 1, S389-S409, 1991.

Schott, F., and C. W. Böning, The WOCE model in the western equatorial Atlantic: Upper-layer circulation, J. Geophys. Res., 96 6993-7004, 1991.

Schott, F., J. Fischer, J. Reppin, and U. Send, On mean and seasonal currents and transports at the western boundary of the equatorial Atlantic, J. Geophys. Res., 98, 14,353-14,368, 1993.

Send, U., The accuracy of current profile measurements: Effect of tropical and mid-latitude internal waves, J. Geophys. Res., 99, 16,229-16,236, 1994.

Silveira, I. C. A., L. B. de Miranda, and W. S. Brown, On the origins of the North Brazil Current, J. Geophys. Res., 99, 22.501-22,512, 1994.

Stalcup, M. C., and W. G. Metcalf, Direct measurements of the Atlantic Equatorial Undercurrent, J. Mar. Res., 24, 44-55, 1966.

Stramma, L., Geostrophic transport of the South Equatorial Current in the Atlantic, J. Mar. Res., 49, 281-294, 1991.

Stramma, L., J. Fischer, and J. Reppin, The North Brazil Undercurrent, Deep Sea Res., Part I, 42, 773-795, 1995.

Tsuchiya. M., Thermostads and circulation in the upper layer of the Atlantic Ocean, Prog. Oceanogr., 16, 235-267, 1986.

Tsuchiya, M., Circulation of the Antarctic Ocean Intermediate Water in the North Atlantic Ocean. J. Mar. Res., 47, 747-755, 1989.

Tsuchiya, M., R. Lukas, R. A. Fine, E. Firing, and E. Lindstrom, Source waters of the Pacific Equatorial Undercurrent, Prog. Oceanogr., 23, 101-147, 1989.

Weisberg, R. H., and T. J. Weingartner, Instability waves in the equatorial Atlantic Ocean, J. Phys. Oceanogr., 18, 1641-1657, 1988.

Wilson, W. D., E. Johns, and R. L. Molinari, Upper layer in the western tropical North Atlantic Ocean during August 1989, J. Geophys. Res., 99, 22.513-22.523, 1994.

J. Fischer, F. A. Schott, and L. Stramma. Institut für Meereskunde an der Universität Kiel, Dïsternbrooker Weg 20, 24105 Kiel, Federal Republic of Germany. (e-mail: fschott@ifm.uni.kiel.d400.de)

(Received March 8, 1995; revised July 20, 1995; accepted September 11, 1995.) 